\title{
Claas Kirchhelle - Giants On Clay Feet - COVID-19, infection control, and public health laboratory networks in England, the US, and (West-)Germany (1945-2020)
}

Dr Claas Kirchhelle, School of History, University College Dublin, Ireland.

\begin{abstract}
COVID-19 has exposed significant differences in public health systems' ability to mount effective test and trace responses. This article analyses the historical and structural reasons behind the relative success of Germany and the problems experienced in Britain and the US during the first wave of the pandemic. It also asks why recent international surveys overestimated Anglo-American preparedness. The article argues that the answer lies in the different evolution of public health systems as well as varying public health capacities at the local level. In Germany, post-1994 reforms of the decentralised public health system managed to overcome decades of political neglect and underinvestment and strengthen federal integration without compromising public health capacity at the state and communal level. This joint strengthening of the centre and hinterland allowed the Robert Koch Institute to function as an effective coordinating hub for locally tailored COVID-19 responses. By contrast, the decades after 1970 saw world-renowned Anglo-American public health systems face increasing challenges posed by funding cuts, privatisation, overambitious reforms, and increasing loss of political autonomy. Both the US Centers for Disease Control and Prevention and Public Health England retained significant prestige, which resulted in an overestimation of capacity by international reviews. However, once centres in Atlanta and Colindale had been overwhelmed, there was little local and state public health capacity to fall back on.
\end{abstract}




\section{Introduction}

The 2020 COVID-19 pandemic poses the most significant challenge to global disease surveillance since the inception of modern public health laboratory networks in the 1940s. SARS-CoV-2 emerged in China in late November 2019 ${ }^{1}$. The first reported human case was identified on December $8^{\text {th }}$. By December $31^{\text {st }}$, Wuhan health authorities reported a cluster of pneumonia in a local wet market and Chinese officials initiated emergency monitoring on January $3^{\text {rd } 2}$. Respiratory, blood, and stool samples were subsequently shipped to designated reference laboratories where next-generation sequencing and real-time reverse transcriptionPCR enabled researchers to identify viral RNA, isolate the novel coronavirus, and develop a PCR-based diagnostic test ${ }^{2,3}$. On January $8^{\text {th }}$, Chinese authorities announced the outbreak of a novel coronavirus. Two days later, a research consortium uploaded the full genetic sequence of COVID-19 to the GenBank database (accession MN908947) and the Global Initiative for Sharing All Influenza Data. The World Health Organization (WHO) simultaneously published technical guidance on PCR-based tests and the detection of potential cases. By the time a public health emergency of international concern was declared on January $30^{\text {th }}$, there was mounting evidence that SARS-CoV-2 had escaped Wuhan, which had been locked down on January $23^{\text {rd }}$ 4. The first foreign case of COVID-19 was reported in Thailand on January $13^{\text {th }}$ and retrospective studies indicate its presence in European patient respiratory and influent wastewater samples from December $2019^{5,6}$.

Despite the speed with which molecular diagnostics were developed, the rapid spread of SARS-CoV-2 has exposed marked differences in the abilities of different public health systems to contain it. In the absence of effective treatments or vaccines, the classic public health tools of testing, contact tracing, and isolation are the most effective means of containing COVID-19. On March $16^{\text {th }}$, WHO director Tedros Adhanom Ghebreyesus acknowledged this by calling on all nations to "test, test, test" . Authorities in South Korea, Taiwan, Singapore, 
Hong Kong, and Vietnam with experiences of SARS (2003) and MERS (2012) and strong surveillance programs $^{8}$ were already mounting rapid test, track, and isolation responses ${ }^{9}$. Reactions were more varied in Europe and North America. Whereas Germany quickly upscaled testing and contact tracing, the US and UK were comparatively slow to expand testing in response to international introductions and domestic transmission. Delayed lockdowns and limited surveillance facilitated the spread of COVID-19 and exacerbated stresses on AngloAmerican laboratory systems. Ultimately, Britain and the US - the two countries considered best prepared for pandemic incidents by recent international reviews ${ }^{10}$ - are suffering the worst outcomes of all G7 countries in terms of fatalities and case numbers.

Many commentators have already highlighted important contributing factors such as political leadership, waning trust in health authorities, differences in social welfare coverage, and individual management failings ${ }^{11-14}$. However, few have taken into account deeper structural path dependencies such as the different design of public health laboratory systems and an ability to integrate national and community-level surveillance. Focusing on the UK, US, and Germany, this article analyses the evolution of national laboratory networks from the 1940s onwards and highlights the impact of different designs, reforms, and new technologies on systems' ability to control infectious disease. It argues that the ability of officials to simultaneously draw on competent central guidance and on a robust hinterland of local public health workers and laboratories has played a key role in containing COVID-19. Despite also experiencing coordination problems ${ }^{15}$, the traditionally communal focus of German public health, the post-1994 integration of testing networks, and the ability to incorporate testing by commercial laboratories allowed for a rapid and flexible rollout of surveillance and contact tracing. Coordinating rather than controlling measures, the Robert Koch Institute (RKI) could rely on sufficiently funded and comparatively autonomous state public health networks and avoided being overwhelmed. The government's February $28^{\text {th }}$ decision to require insurers to 
reimburse COVID-19 tests also incentivised private laboratories to create additional testing capacity before the full pandemic wave hit ${ }^{16}$.

By contrast, the ability of the US and UK authorities to react was severely constrained by decades of cuts to national and regional public health budgets, reforms compromising the autonomy of public health bodies, and attempts to commercialise core public health functions. Both the US Centers for Disease Control and Prevention (CDC) and Public Health England (PHE) are major hubs of excellence in infectious disease control and have a successful track record of projecting soft power abroad. However, they also proved to be giants on clay feet. By 2020, PHE no longer had an integrated hinterland of multiple local public health laboratories and the CDC had never been designed to exert significant control over increasingly underfunded public health within US states. Once national centres of expertise were overwhelmed, Anglo-American authorities struggled to redesign, upscale, and integrate testing regimes.

Problems were exacerbated by confused decision-making and individual institutional failings such as distributing flawed testing kits. The UK experienced over 1,356 separate introductions of SARS-Cov-2 by May $22^{\text {nd }} 17$ but held fast to a containment phase focusing on traveller surveillance until March $12^{\text {th }}$. It also followed a sequential approach to testing, which limited initial testing to PHE's Colindale campus and was comparatively slow to enable country-wide testing by other laboratories ${ }^{18}$. In the US, a national emergency was only declared on March $13^{\text {th }} 19$ by which time the virus was already widely circulating ${ }^{20}$. In both countries, upscaling of testing and contact tracing was eventually achieved as a result of significant outsourcing of core public health functions to commercial contractors like Deloitte and Serco, volunteering by the scientific community, and - in the case of Nebraska - pool testing up to five samples for the presence of the virus ${ }^{21,22}$. Questions have since been asked about the allocation of contracts and lack of data sharing with local authorities ${ }^{23,24}$. Politically, the CDC 
may experience restructuring in the near future. In Britain, the government has already announced that it will replace PHE with a new National Institute for Health Protection ${ }^{25-27}$, which will integrate the NHS test and trace system and Joint Biosecurity Centre. 


\section{Part One: From Patchwork to Control (1900-1970)}

Public health has always stood at the crossroads of politics and science. The roots of modern public health date back to the mid- $19^{\text {th }}$ century when a diverse group of campaigners used new statistics-based approaches to study population health and lobby for preventive interventions. In contrast to the concerns of medical practitioners for the health of the individual, public health campaigners focused on ensuring the health of the collective and often formed close alliances with state and colonial authorities. Containing the spread of disease was a natural focus of this alliance and was greatly aided by the advent of germ theory from the 1860 s onwards $^{28-33}$.

By around 1900, many European and North American cities were implementing sanitary safeguards for water and food supplies and began to roll out vaccines and culture and serology-based testing to local populations ${ }^{34}$. Under the aegis of the new discipline of Tropical Medicine, public health measures were also being implemented in colonial settings and in major trade ports ${ }^{35-37}$. The discovery of 'healthy' asymptomatic carriers of typhoid, diphtheria, and tuberculosis complicated early models of disease control ${ }^{38-41}$. With overall rates of infectious disease already falling, public health authorities in richer countries became increasingly interested in applying bacteriology to 'hunt' for environmental and human reservoirs of microbial disease ${ }^{42}$.

Key to this 'hunt' was the integration of clinical, laboratory, and epidemiological resources. World War One saw major powers deploy a mix of sanitary measures, vaccination, and mass-testing to curb the spread of diseases like syphilis, smallpox, or typhoid. Although measures helped limit wartime outbreaks, the health crisis caused by the Spanish Flu pandemic (H1N1), difficulties in explaining type variation, and civilian rejection of intrusive surveillance led to a post-war crisis of classic bacteriology and a dissolution of wartime integration ${ }^{38,40,43-}$ 47. The crisis of surveillance did not last long. By the 1930s, growing state involvement in medical and social care, clinical demand for testing, and fears of bacteriological warfare 
triggered a renewed expansion and integration of public health laboratory networks. This process was aided by new serological, phage-based, and other typing systems. These systems could identify microbes below the species level but required high levels of standardisation and integration to be effective ${ }^{48-50}$. Emerging laboratory networks were shaped by their sociopolitical context.

British public health laboratories arose unsystematically at the local level as a result of 1875 public health act, philanthropy, and 1899 disease notification requirements. Although calls for a cohesive national pathology service dated back to 1913, Britain's Ministry of Health (est. 1919) and Medical Research Council (MRC) (est. 1913) only slowly began to consolidate preventive and research activities during the interwar period ${ }^{28}$. A limited amount of central surveillance and coordination was conducted by London's Lister Institute and a three-man Ministry of Health laboratory on Endell Street, which was "depressing in [its] appearance and poorly equipped" ${ }^{51}$. Beyond this, most investigations continued to be carried out in a decentralised fashion by local medical officers of health (MoHs), a few dedicated communal public health laboratories, and commercial, hospital, and university laboratories - who did not always report findings to the responsible $\mathrm{MoH}^{28,34}$. In 1939, an incomplete survey counted at least 32 county or municipal labs across England and Wales ${ }^{52}$.

Concerns about the ability of Britain's fragmented laboratory system to respond to new forms of bacteriological warfare were voiced by the Committee of Imperial Defence in 1934 and led to the establishment of a Subcommittee on bacteriological Warfare in November 1936. In the case of war, it was decided to establish a centralized emergency laboratory network spanning urban and rural areas across England and Wales (Scotland, Northern Ireland, and London had distinct arrangements). The Emergency Public Health Laboratory Service (EPHLS) would protect troops and civilians from epidemics and bacteriological sabotage. A 'sister' organisation at Porton Down would develop offensive and defensive capabilities ${ }^{51}$. 
The EPHLS was mobilized as part of the newly centralized Emergency Medical Services one week before the declaration of war on September $3^{\text {rd }}, 1939$. An integrated network of 19 laboratories was set up across England and Wales with provincial laboratories reporting back to a central laboratory safely headquartered in Oxford. Despite complaints from commercial laboratories, the ability of EPHLS to offer free epidemiological, microbiological, and other laboratory services soon convinced MoHs and health professionals to collaborate with the new organisation. The collaboration held mutual benefits. At the local level, disease control was boosted with the help of free EPHLS laboratories and experts. Standardised data and processing (rising from 929 to 247,214 specimens per month between October 1939 and December 1941) $)^{53}$ helped EPHLS researchers survey national health and uncover interlinked outbreaks that would have remained invisible to local investigators ${ }^{53,54}$.

In the absence of bacteriological attacks, EPHLS research also produced effective new surveillance technologies: national phage-typing schemes were rolled out for typhoid, paratyphoid, Salmonella enterica serovar Typhimurium, and Staphylococcus aureus; 'Moore swabs' were developed to isolate and trace bacteria in sewer and water systems; centralized 'finger print registries' for typhoid carriers were established; and microbial taxonomies were refined $^{28,53-56}$. Its track record secured the EPHLS a post-war future. Although Britain's National Health Service (NHS) (est. 1948) divorced public health from medical care and maintained its own microbiology services, the renamed PHLS (est. 1946) managed to maintain a cohesive laboratory network. Many PHLS laboratories' location in hospitals and close ties to MoHs allowed for rapid and flexible responses to local problems. Between 1947 and 1953, the PHLS expanded from 28 to 60 laboratories. Headquartered in Colindale, it also began to play a prestigious international role through managing international reference laboratories for salmonella and staphylococci ${ }^{53,57-61}$. The creation of a PHLS Epidemiological Research Laboratory during the late $1950 \mathrm{~s}$ and the weekly publication of microbiological and 
epidemiological information further strengthened British disease surveillance ${ }^{62}$. In 1960, the PHLS Act transferred responsibility for the PHLS from the MRC to the Ministry of Health thereby establishing the PHLS as a specific body within Britain's health protection structure ${ }^{52}$.

Integrating surveillance and using public health to project soft power abroad was not only popular in Britain. In the US, public health laboratories also emerged in the late $19^{\text {th }}$ century. In 1887, a National Hygienic Laboratory (predecessor of the National Institutes of Health) was established at the Marine Hospital in Staten Island. By 1907, all US states had boards of health, which were supplemented by local and county health departments ${ }^{63}$. In 1914 , 47 of 48 states reported having established dedicated public health laboratories ${ }^{64-66}$. National organisations like the State Laboratory Directors Conference (est. 1927, now Association of Public Health Laboratories (APHL)) and Association of State and Territorial Health Officials (est. 1942) were established to coordinate activities and large-scale Rockefeller Foundation funding for disease control further boosted laboratory capacity ${ }^{67}$.

Because responsibility for infection control rested with individual states ${ }^{68}$, federal officials focused on inter-state surveillance and assisting state-level programs ${ }^{69}$. During the interwar period, the Public Health Service (PHS), United States Department of Agriculture (USDA), and newly founded Food and Drug Administration (FDA) stepped in to stop human, animal, and plant diseases from crossing state borders. The PHS also supported states with the control of venereal disease and malaria and collected data on 29 notifiable diseases ${ }^{68,70,71}$. Legislative reforms increased ties between federal and state authorities. The 1935 Social Security Act provided a permanent machinery for the distribution of federal funds via grantin-aid to state and larger local health departments and the 1938 National Venereal Disease Control Act released significant funds for state-based interventions ${ }^{64,72}$.

Despite improved interwar coordination of state services, there remained considerable variation in the quality, number, and speed of laboratory services US citizens could access. 
Free official public health laboratory services were unevenly distributed with poorer and rural areas enjoying less coverage than wealthier and metropolitan areas. Responding to these gaps, a growing number of commercial mail-order and hospital-based pathology laboratories offered for-profit tests for various diseases. Quality concerns led to attempts by professional societies to regulate commercial services via approved laboratory lists and standardised training curricula $^{73}$.

Using rising microbiological testing data for epidemiological surveillance also proved challenging. In so-called centralized states, state health authorities operated local health departments as branches. In de-centralized states, local health departments were financed by local governments and retained more authority and responsibility for the delivery of public health services ${ }^{74}$. Problems were compounded by frayed state-level responsibilities. In 1940, a PHS survey came to the "somewhat startling" realization that "within a single State as many as 18 separate agencies contribute something to the health activities" and that "no jurisdiction" had less than "6 agencies involved" 75 . Communicable disease responsibility was mostly located within state health departments, but additional responsibilities could be located in as many as eight other agencies. Notification practices, testing facilities, and quality control also varied ${ }^{75}$. Lack of quality control impacted the reliability of testing. As a result of the 1938 Venereal Disease Law and marital examination laws, syphilis testing occupied two thirds of US states' entire diagnostic laboratory work. However, only 16 states regularly assessed the gold standard Wassermann tests and only nine controlled diagnostics for other diseases ${ }^{75}$. Funding differences exacerbated differences in state public health performance. In 1940, US states spent ca. $\$ 285$ million on public health (ca. $\$ 1.90$ per capita). However, Tennessee only spent $\$ 0.76$ per inhabitant whereas New York spent \$3.27 and Hawaii \$5.03

For US disease control to evolve, there was a need to further improve coordination between federal and state authorities, expand services, and standardise laboratory and reporting 
protocols. Attempts to remedy this situation occurred at the local, state, and federal levels. By $1950,86 \%$ of the US citizens were served by a local health department and over 34,000 persons were employed full-time in various public health agencies ${ }^{63}$. The 1944 Public Health Service Act also strengthened central oversight by specifying a federal coordinating role over US public health $^{62}$. From 1951, PHS officials and the Council of State and Territorial Epidemiologists began to meet annually to decide on a list of diseases to be reported by states. Notified data was soon compiled and published on a weekly basis in what would become the Morbidity and Mortality Weekly Report ${ }^{62,65}{ }^{i}$

The biggest innovation to come out of the 1940s reordering of US public health was the CDC. Originating in wartime malaria and typhus control programs, the CDC was established as the Center for Disease Control in 1946. As an initially obscure federal department outside Washington DC, the young agency had to convince Congress, the PHS, and individual states to finance its activities and transfer powers ${ }^{76,77}$. Another challenge lay in expanding its remit from vector-borne to other diseases. Boosted by contemporary biological warfare fears, the CDC solved both challenges. Between 1950 and 1960, it acquired responsibility for federal disease responses (1950), established a national network of assigned typing laboratories (1951), acquired responsibility for venereal disease (1957) and tuberculosis control (1960), and oversaw programs against polio (1955), influenza (1957), and nosocomial infections $(1957)^{78-}$ ${ }^{80}$. According to famed CDC epidemiologist Alexander Langmuir, good surveillance depended on constant data gathering, effective integration and analysis, and good communication:

Surveillance, when applied to a disease, means the continued watchfulness over the distribution and trends of incidence through the systematic collection, consolidation and evaluation of morbidity and mortality reports and other relevant data. Intrinsic in the concept is the regular dissemination of the basic data and interpretations to all who have contributed and to all others who need to know. The concept, however, does not

${ }^{\mathrm{i}}$ Less comprehensive predecessor reports had been published by the PHS since 1930 (Weekly Health Index (1930-1941), Weekly Mortality Index (1941-1952), Morbidity and Mortality (1952-1975), Morbidity and Mortality Weekly Report (1976-present). 
encompass direct responsibility for control activities. These traditionally have been and still remain with the state and local health authorities ${ }^{81}$.

By the 1960s, its surveillance, training, research, and emergency response programs had turned the CDC into the foremost public health agency in the US ${ }^{79}$. The CDC also gained international renown and directed the International Influenza Center for the Americas, the International Shigella Centre, and the WHO serological reference centre for syphilis. The 1969 Clinical Laboratories Improvement Act further expanded CDC powers by giving it the authority to license clinical laboratories soliciting or accepting specimens in interstate commerce $^{79}$. However, in contrast to the PHLS, the CDC never acquired direct control over state laboratories and continued to work as a national coordinator and provider of finance, services, and training ${ }^{76}$.

Whereas post-war Britain adopted a centralised laboratory system and the US an integrated service-type arrangement, West Germany's public health laboratory system evolved in a bottom-up fashion. During the Kaiserreich, German bacteriology had achieved international renown but remained decentralised outside of Prussia and the military. By 1911, there were over 50 official bacteriological institutes across the German states ${ }^{82}$. Centralisation efforts occurred during World War One and the Nazi era and there were many close connections between leading bacteriologists at the Reichsgesundheitsamt, the military, state health departments and hygiene institutes, and the Robert Koch Institut (RKI). However, their active support of Nazi racial hygiene meant that large parts of the German public health establishment fell into disrepute after 1945. In West Germany, prime responsibility for public health surveillance and enforcement was decentralized and firmly re-embedded in the Federal Republic's 11 states (Bundesländer) and powerful municipalities (Kommunen $)^{43,83-85}$.

In contrast to communist East Germany's centralised health and public health systems, West Germany's federal government acted as a 'manager' enacting compromises between different parts of a complex health system. This system consisted of ca. 500 local and 
communal health offices (Gesundheitsämter), 11 state health departments (Landesgesundheitsämter), over 1,300 statutory health insurers covering about $90 \%$ of the population, and powerful practitioner and hospital associations ${ }^{86}$. Federal authority for public health rested with the Federal Office of Health (Bundesgesundheitsamt) ${ }^{\mathrm{ii}}$, the Federal Ministry of Health (Bundesgesundheitsministerium, est. 1961), and the Conference of Health Ministers of the Federal States (Gesundheitsministerkonferenz). Below the federal level, some states like Bavaria had integrated public health systems while others relied on communal arrangements with loose coordination via state health departments ${ }^{86-88}$.

Fragmented responsibilities and the divorce of state-funded public health from insurance-funded curative medicine led to a long-term stagnation of the former ${ }^{88}$. By the $1970 \mathrm{~s}$, relative oversupplies of hospital beds and doctors ${ }^{86,88}$ contrasted with withering investment in West German public health and laboratory capacity. Despite strong inter-German rivalry over health indicators, West Germany did not systematically boost or integrate public health services $^{89-91}$. According to a 1985 WHO-commissioned review, post-war planning "explicitly directed towards improving the health of the population, improving the effectiveness and quality of health care, or intensifying protection against illness" was "minimal" 86 . Although the number of public health positions per 1,000 inhabitants remained stable on paper, low salaries and prestige led to recruitment problems and a significant number of vacancies ${ }^{88}$.

While some reviewers noted that West German decentralisation created a certain "flexibility" 86 , lack of integration negatively impacted disease surveillance. There was limited coordination at the federal and state level via stakeholder conferences and circulars ${ }^{87}$. Local public health laboratories could also request specialist assistance from universities, the RKI

\footnotetext{
ii From 1969 to 1986 Federal Ministry of Youth, Family and Health, from 1986 to 1991 Federal Ministry for Youth, Family, Women, and Health. Responsibility for the statutory health insurance system was shared with the Federal Ministry of Labour and Social Affairs.
} 
(part of the Federal Health Office from 1952 to 1994), or Hamburg's Bernhard Nocht Institute for Tropical Medicine. However, health sector rivalries and lacking federal interest meant that infectious disease control remained neglected. The Federal Health Ministry only began publishing internationally comparable disease statistics in 1963, there was no regular and comprehensive assessment of health statistics, and no West German institution could rival the PHLS or CDC as an international authority for public health training and research ${ }^{86,88}$.

The ongoing post-war decline of infectious disease, which was underpinned by effective sanitation, vaccination, antibiotics, and rising wealth, seemingly validated the varying approaches chosen in each of the three analysed countries. While West German public health stagnated, Cold War competition and international health programs strengthened the influence of the PHLS and CDC over laboratory systems in other parts of the world $1,76,92-94$. The ongoing decline of infectious disease also facilitated a shift of resources towards chronic and noncommunicable diseases $^{95-98}$. Despite concerns about antimicrobial resistance (AMR), many observers started to believe that infectious disease no longer posed a major threat to public health $54,57,99,100$. 


\section{Part Two: Neglect (1970s-1988)}

During the 1970s and 1980s, the perceived decline of communicable disease and fiscal constraints triggered an increasing stagnation of laboratory-based pathogen surveillance and a wider reordering of public health. Consequences were felt unevenly: comparatively wellfunded centres like the CDC and PHLS began to use new molecular technologies and integrated information technology (IT) networks to transform public health surveillance from a mostly "archival function" to "one in which there is timely analysis of the data with an appropriate response" ${ }^{65}$. However, in the shadow of these prominent sentinels, the hinterland of regional and local public health laboratories in all three countries started declining.

In the UK, the 1974 NHS reforms transformed public health in favour of a more hospitalcentric management-oriented approach. Since 1939, close local collaborations between relatively autonomous PHLS labs, MoHs, and clinicians had been a hallmark of British public health ${ }^{101}$. However, in 1974, the once powerful office of the MoH was disbanded. With Britain's welfare state expanding, the 1974 reforms aimed to improve the management, quality, and integration of social and health services by transferring the responsibilities of local authorities for personal health services outside hospitals to new NHS regional and area health authorities $^{102}$. The importance of MoHs had already declined as a result of the expanding role of GPs in maternal and child health and the removal of social care from their remit by the 1968 Seebohm Report ${ }^{103}$. In 1974, MoHs' remaining duties were distributed among other local authority and NHS services ${ }^{88}$. Local authorities retained environmental and some public health services, GPs remained responsible for maternal and child health, and community physicians with ill-defined preventive health duties were appointed to NHS regional, district, and area authorities ${ }^{103,104}$. Fragmented responsibilities undermined community-level public health ${ }^{88}$. According to later estimates, the 1974 reorganisation also resulted in the early retirement or dispersal of ca. 400 highly-skilled public health doctors ${ }^{62}$. 
Times were also changing for the PHLS. Since 1946, the PHLS laboratory network had continued to expand before reaching its maximum extent in 1969. A large part of this growth was achieved by establishing dual purpose laboratories that were embedded in NHS hospitals and conducted both public health and clinical microbiology. By 1969, 42 of 63 PHLS constituent laboratories were providing general bacteriological services to the hospitals they were based in, 13 were supplying some kind of bacteriological service to a hospital, and only eight were solely conducting public health research ${ }^{53}$. The advantages to the PHLS were obvious: clinical microbiology generated revenue and data on infection levels, enabled close relations with clinicians, and facilitated rapid outbreak responses. However, existing arrangements also made NHS clinical pathologists accuse the PHLS of 'poaching' their work $^{105-107}$. In 1966, it was agreed that the PHLS should only provide services to local hospitals if invited to do $\mathrm{so}^{53}$. Three years later, a review of PHLS activity recommended against further merging clinical and public health microbiology. PHLS core tasks were now defined as "to make a continuous study of how microbial diseases are spread, and what advice should be given for their control" ${ }^{\text {53 }}$. The PHLS would remain present in British hospitals. However, it would have to close 13 of its 63 laboratories over the next 10 years.

Although the PHLS managed to secure the reassignment of its laboratory staff, the 1970s fiscal crisis and growing government emphasis on lifestyle change over traditional public health interventions created pressure for cost-effective microbiology services ${ }^{108}$. In response, the PHLS invested in the computerisation and the automation of testing at Colindale. Concerns about new viral haemorrhagic fevers and a slow response to the 1973 smallpox release at the London School of Hygiene and Tropical Medicine also led to the decision to better integrate microbiological and epidemiological services ${ }^{62}$. In 1977, Britain emulated the CDC by founding the PHLS Communicable Disease Surveillance Centre (CDSC). Housed in Colindale, 
the CDSC quickly became an important research hub and achieved national prominence by quickly reacting to the 1977 Birmingham smallpox outbreak ${ }^{53,109}$.

Despite increasing the efficiency, volume, and integration of its services, pressures on the PHLS continued to increase: the disappearance of MoHs weakened relations with community public health workers; the ad hoc nature of 1970s lab closures increased discrepancies between a better served south and a more poorly served north of England ${ }^{53}$; fiscal constraints forced the PHLS to press NHS authorities for more compensation of microbiological services ${ }^{53}$. From 1979 onwards, there was also concern about the new Thatcher administration's focus on cost cutting reviews. In 1985, a Department of Health and Social Services (DHSS) review recommended a radical transfer of the PHLS' 52 area and regional public health laboratories to NHS health authorities ${ }^{110,111}$. The proposal prompted fierce criticism from British health professionals. Writing in 1985, former PHLS director James Howie warned against demoting the PHLS to a consulting epidemiological service and breaking up a laboratory network that connected public health experts in London to the rest of the country:

So the PHLS is at a crossroads. Starved of funds, it can maintain its national laboratory service only at the expense of curtailing its epidemiological activities - or conversely maintain or increase its epidemiological activities only at the expense of the laboratory service. (...). What seems plain is that [NHS] district health authorities have neither the incentive nor the powers to get going measures of action and investigation covering regions wider than their own. (...). [The PHLS] is admired and envied for its effective peripheral contacts by its counterpart in the United States (...). Those who would break the essential PHLS links between centre and periphery - who are they? Do they really know what they are doing? ${ }^{112}$

The DHSS review prompted a merger of the PHLS Epidemiological Research Service and CDSC. However, medical criticism, rising numbers of domestic disease outbreaks, and the contemporary HIV/AIDS crisis made the Thatcher government decide to maintain the wider PHLS laboratory network ${ }^{112-117}$. Howie's warnings nonetheless proved prescient: by the early 1990 s, further budget cuts, attempts to recoup costs, and politicised responses to health crises began to threaten core PHLS capabilities and the wartime integration of local and national public health ${ }^{118,119}$. 
The increasing discrepancy between a still powerful centre and relative underinvestment in the public health hinterland was mirrored in the US. Internationally, the CDC remained a poster child due to its disease control and eradication efforts and research on new pathogens (e.g. haemorrhagic fevers like Lassa, Marburg, and Ebola) $)^{94,120,121}$. However, outside of Atlanta, US politicians' commitment to infectious disease control and surveillance was waning. In the fiscal year 1973/1974, there were 12,295 clinical and public health laboratories in the US. Around 3 percent (392) of these were official state and local public health laboratories, which performed ca. 70 million laboratory tests per year $(2 \%$ of total laboratory examinations) $)^{122}$. Per capita expenditure and the number of analysed public health specimens increased throughout the 1960 s and $1970 \mathrm{~s}^{123}$. This increase was, however, driven less by classic work on communicable disease ${ }^{123}$ than by toxicological, microbiological, and chemical testing related to growing concerns about chronic disease and environmental health ${ }^{123,124}$. Rising per capita expenditure also belied increasing understaffing in public health laboratories. After peaking at 6,598 in 1975 , the number of budgeted positions in territorial public health laboratories declined to 5,603 (-17.8\%) in $1982^{123}$. Recruitment problems meant that many budgeted positions remained unfilled with a vacancy rate of $11 \%$ reported in $1979^{125}$. Whereas free public health testing had traditionally been viewed as an essential service, fiscal pressure, competition from commercial laboratories, and the retreat of universities from public health made an increasing number of public health laboratories charge fees. Additional problems resulting from lack of coordination, underinvestment in laboratory improvement, and 'red tape' prompted some commentators to call for an abandonment of all free routine testing and a concentration of public resources on specialist reference services ${ }^{122,126}$.

The CDC in Atlanta was not exempt from fiscal pressure. Promoted to the rank of PHS Bureau in 1968, the CDC had strategically acquired new competencies in areas unrelated to communicable disease including nutrition, occupational safety, smoking, and environmental 
health ${ }^{76}$. To reflect this ambition, it was renamed Center for Disease Control in $1970^{127}$. However, after moving from success to success, the 1970s also saw the CDC experience a series of setbacks. Starting in 1974, successive US administrations responded to surging inflation and economic stagnation (stagflation) by first imposing limits and then cuts on federal expenditure. In 1976, the CDC suffered additional damage due to its advocacy of mass vaccination against swine flu (H1N1). The significant cost of the campaign, absence of a predicted pandemic, and cases of vaccine-induced Guillain-Barré syndrome led to the sacking of long-standing CDC director David J. Sencer and triggered a CDC reorganization. In line with the Surgeon General's 1979 call for a second public health revolution centring on preventive health, the CDC was renamed into Centers for Disease Control and Prevention and focused more resources on lifestyle and environmental issues ${ }^{76,127}$. Following Ronald Reagan's election, Sencer's successor William Foege was also forced to administer severe cuts of federal public health funding ${ }^{128}$. Despite the parallel emergence of HIV/AIDS in the US, the CDC announced it was considering laying off between 350 and 780 of its 3700 employees in 1982 with about half of layoffs planned in the area of infectious disease ${ }^{76,129}$. Between 1981 and 1983, the CDC's staff-year ceiling sunk from 4,249 to 4,045 years (-4.8 percent). Further cuts between 1985 and 1988 further reduced the ceiling for original departments to 3,904 staff years $(-8.12 \text { percent })^{130}$.

While the US and UK witnessed an erosion of local public health capacity and growing challenges to their national centres of expertise, West German arrangements were relatively static: local Gesundheitsämter remained responsible for most public health testing and enforcement; state offices compiled data, aided outbreak responses, and administered health programs; federal activity focused mostly on state coordination. Efficiency was limited. According to a 1976 survey of venereal disease control, public health workers lacked power in relation to insurance-financed clinicians. Many clinicians did not adhere to updated 1970 
disease reporting requirements and had monopolized lucrative treatments. The small number of local Gesundheitsämter offering consultative services had to refer patients to local practitioners. Systematised testing was limited, disease incidence was underreported, and data was insufficient to allow for effective contact tracing ${ }^{131}$. Public health's low status and the absence of comprehensive data made it difficult to recruit talented workers or to convince politicians of the economic value of public health ${ }^{132}$.

Post-war resistance of the West German states to federal centralisation gradually diminished from the 1970s onwards. However, attempts to update disease reporting, improve integration, and expand coverage with 1972 "guidelines for federal state law on public health" and 1977 "Concerted action in the public health sector" failed to resolve problems ${ }^{86,87,91}$. There were limited updates of state health service provisions ${ }^{87}$ and dental and preventive services were rolled out to wider population segments ${ }^{91}$. However, key responsibilities were assigned not to the Gesundheitsämter but to ambulatory care physicians, who were reimbursed by sickness funds. The result was a further exodus of public health workers. Between 1970 and 1996, the number of physicians working in West German public health services decreased from 4,900 to 3,300 , the number of dentists from 2500 to 800 , and the number of social workers from 4,000 to 2,500 . . Lack of political interest and planning towards "intensifying protection against illness" $" 86$ was also reflected in scientific guidance. In 1975, the Bundesgesundheitsamt recruited 50 experts to develop recommendations on nosocomial infections. However, in contrast to contemporary Anglo-American programs, resulting guidelines on architecture and technical procedures did not cite systematic reviews or clinical studies ${ }^{133}$. External reviews of West Germany were harsh. A 1991 assessment found health services to be both "highly decentralized and highly formalized" - public health services were "weak" and "something of a poor relation" 134 . Immunization rates were comparatively low and reported infectious disease mortality was over $40 \%$ in excess of East Germany ${ }^{135}$. 


\section{Part Three: Clay Feet (1988-2020)}

Serious concerns about Western public health systems' continued ability to deal with infectious disease threats emerged amidst surging rates of AMR, nosocomial and foodborne infections, and outbreaks of emerging diseases around 1990.

In Britain, HIV/AIDS and fatal outbreaks of salmonellosis at a mental health unit at Wakefield's Stanley Royd Hospital (1984) and of legionella at Stafford General Hospital (1985) triggered a review of public health services. Headed by Chief Medical Officer (CMO) Donald Acheson, the review's influential 1988 report stated that the 1974 NHS reorganisation had harmed public health at the community level ${ }^{136}$. Reforms had not resulted in effective cooperation between hospital specialists, community physicians, and environmental health officers. MoHs had once formed a public health anchor point for local authorities, GPs, and hospitals. However, after 1974, ill-defined NHS and local authority responsibilities had led to a neglect of preventive health and communicable disease control ${ }^{136}$. This neglect had been exacerbated by 1982/1983 managerial reforms, which abolished NHS area authorities and resulted in the retirement of $20 \%$ of community physicians - many of them former MoHs -, recruitment problems, and low morale ${ }^{102,104}$. In the case of infectious disease, it was "extremely important (...) that someone within the health authority is responsible for linking the vital work undertaken by microbiologists and control of infection teams within hospitals with cases of infection occurring outside" ${ }^{102}$. Effective control was also hampered by funding and integration problems within the PHLS:

Evidence submitted to us demonstrates almost universal support for the PHLS and its epidemiological 'nerve centre' the CDSC. (...) there is a widespread view that CDSC is under-resourced. (...). We are concerned to learn that if there were a recurrence of serious outbreaks $(. .$.$) in more than one part of the country at the same time, or if a single outbreak$ spread to more than one major centre of population, the current system would be unable to cope $^{102}$.

To strengthen community-level disease control, the 1988 Acheson report recommended creating the post of a medically qualified District Control of Infection Officer (eventually called Consultant for Communicable Disease Control (CCDC)), who would provide advice for local 
public health and clinical services. A second new post, the Director of Public Health (DPH), would work with the CCDC, coordinate preventive health at the district level, and submit public health annual reports ${ }^{102,137}$. CCDCs would also be part of an advisory District Control of Infection Committee and would receive district and regional NHS support for contact tracing and public health education ${ }^{102}$. At the national level, the PHLS should be strengthened by making it mandatory to report outbreaks to the CDSC rather than the $\mathrm{CMO}$ and granting emergency powers for the CMO to assign responsibility for outbreak investigation to the CDSC. An electronic disease notification system should also be introduced ${ }^{102}$.

While the Acheson report revitalised community public health ${ }^{62}$, government promises to create full NHS consultant posts for infection control trainees fell through and calls for a sustained strengthening of PHLS funding went unheard ${ }^{137}$. During the 1990 s, the PHLS had to absorb large budget cuts ${ }^{138}$ and faced pressure to prove its cost-effectiveness with value for money (VFM) reviews and new NHS customer arrangements following the introduction of limited market competition ${ }^{139,140}$.

PHLS workers' also faced the challenge of updating phenotypic surveillance methods with new genotypic technologies like pulsed-field gel electrophoresis (PFGE) ${ }^{141}$ and of replacing paper-based with electronic reporting systems without compromising patient confidentiality $^{142,143}$. In 1994, the PHLS established a National Surveillance Group to commission and review protocols for the surveillance of specific infections and also launched an Epidemiology Information Strategy (EITS) to upgrade IT systems ${ }^{62}$. New EU initiatives on transnational AMR monitoring and prospects of rapid near patient testing also triggered the creation of systems that could integrate laboratory and clinical information ${ }^{62,144,145}$.

On the occasion of its 50-year jubilee in 1996, the PHLS remained in command over a network of 49 microbiology laboratories organised into nine regional groups with devolved budgets and could also draw on information supplied by NHS laboratories ${ }^{52}$. However, the 
future of the famed service seemed uncertain. Reflecting on the PHLS' contributions, a Lancet commentary warned: "At a time when the British government seems keen to be penny wise and pound foolish, the message (...) to those who would further pare down an already rationalised PHLS is leave well alone"146.

The US experienced a similar weakening of public health. 1980s cuts to federal and state public health budgets and attempts to commercialise services resulted in a decline of public health laboratory capacity ${ }^{65}$. Between 1977 and 1982, dedicated staffing in state laboratories declined by $6.9 \%{ }^{66}$. From 1981 onwards, Reaganite cuts to new federal block grants triggered proportional cuts of state expenditure on public health administration, environmental health, and laboratory provision ${ }^{66}$. Public health spending also decreased at the local level ${ }^{66}$. Reduced federal, state, and local spending was accompanied by an increase of infectious disease. Between 1980 and 1992, US death rates from infectious diseases rose by over $50 \%$ and once again became the third most common cause of death ${ }^{127}$.

Alarmed, the Institute of Medicine (IoM) published a damning analysis in 1988: "disarray of public health" 66 had resulted from underfunding, reactive policy-making, varying state capabilities, and fragmented services ${ }^{66}$. All but one state conducted laboratory analyses for communicable disease and all screened their population for over 30 health problems ${ }^{66}$. However, the diseases being surveyed and reporting methods varied ${ }^{66}$. To improve public health, the IoM recommended creating regularly reviewed public health strategies. US states were "the central force in public health" but authorities had to do more to guarantee essential functions, expand and integrate data collection, and coordinate and support existing local and state-level services ${ }^{66}$. Congress and the CDC should use federal funds to strengthen public health and balance fiscal disparities between states ${ }^{66}$.

Co-chaired by Nobel Laureate Joshua Lederberg, a second IoM review issued an even sterner call for action in 1992. Titled Emerging Infections: Microbial Threats to Health in the 
United States, the review warned that the US still had no "comprehensive national system for detecting outbreaks of infectious disease (except for food- and waterborne diseases)" and that there was a "lack of coordination among the various US government agencies" and "between government agencies and private organizations"147. New IT systems like the CDC's 1984 Epidemiologic Surveillance Project could significantly improve outbreak identification and response times ${ }^{65}$. However, the adoption of electronic systems outside of the six trial states (Colorado, Michigan, Minnesota, New York, Washington, Wisconsin) ${ }^{62}$ had been slow and many state laboratories still relied on paper forms. In addition to upgrading electronic reporting systems, the IoM recommended that the PHS establish a "comprehensive computerized infectious disease database" 147 to consolidate information from domestic and international programs. Other recommendations included reinstating CDC extramural grants, improving epidemiological training, intensifying research on vaccines and antimicrobial drugs, and creating national stockpiles for future "infectious disease emergencies" ${ }^{147}$. The US should also push for a "comprehensive global infectious disease surveillance system"147.

With US health politics becoming increasingly polarised in view of the Clinton Administration's 1993 attempt to establish universal health coverage, regulatory progress was limited ${ }^{62}$. In 1994, CDC epidemiologists raised alarm about the "crumbling foundation"148 of infectious disease surveillance. The past 12 years had seen growing gaps in state surveillance. According to a 1992 survey, "only skeletal staff exists in many state and local health departments to conduct surveillance for most infectious disease"148. 22 of 23 surveyed state laboratories reported hiring freezes or loss of positions. In the case of foodborne disease, 12 states no longer had any dedicated surveillance personnel ${ }^{149}$. In the case of HIV/AIDS, tuberculosis, and childhood vaccine-preventable diseases, state data had become so unreliable that the CDC had to spend an additional \$20 million per year for AIDS surveillance alone. Federal surveillance for multidrug-resistant TB was discontinued in 1986 before being 
reactivated in 1993 as a result of a significant incidence spike ${ }^{148}$. With the exception of a few states like Washington, public health funding gaps were now the norm. In 1991, 78 towns with a combined population of 882,430 in Connecticut - the wealthiest US state - had no local access to full public health services ${ }^{150}$. According to CDC estimates, US state and PHS spending on public health amounted to ca. \$14.4 billion in 1993 (ca. 1.6 percent of total health expenditure) ${ }^{151}$. Two years later, this figure was corrected downwards to about 1 percent of total health expenditure ${ }^{152}$.

Privatization was another challenge. In contrast to the $\mathrm{UK}^{220}$, private sector testing had remained important in post-war America. Commercial laboratories provided testing for physicians, hospitals, and local authorities ${ }^{66,149}$. The CDC and Association of Public Health Laboratories (APHL) had tried to assure the quality of commercial testing and disease reporting. Success was mixed ${ }^{153}$. Meanwhile, the growing political emphasis on fiscal restraint and management reforms created pressure on public health departments to outsource or commercialise parts of their own testing ${ }^{154}$. In 1992, nearly half of surveyed state laboratory directors indicated that some form of privatization of laboratory activities was under discussion ${ }^{149}$. The resulting economic playing field was uneven. The ability of commercial laboratories to offer bulk testing for a select number of profitable diseases allowed them to undercut public laboratories, which also had to recoup the costs of preserving a broad skill reservoir for advanced testing of uncommon pathogens, maintaining surge capacity, and integrating testing with other public health services ${ }^{154,155}$. Many state laboratories already charged user fees and accepted Medicare fees and third-party reimbursement for some services. However, payment systems proved difficult to establish and not all laboratories were allowed to keep generated revenues ${ }^{149}$. In some cases, privatization had to be reversed after it threatened core services as in the case of commercialised TB and STD testing in New Jersey or of vendor 
instability in Pennsylvania ${ }^{154}$. A 2000 review predicted that uncoordinated commercialisation and weakened surveillance could have dire consequences for US public health ${ }^{154}$.

Responding to the erosion of local- and state-level capabilities, the CDC tried to improve the efficacy of existing networks by updating typing and IT infrastructures. In 1996, it established a network of electronically linked sentinel laboratories that could detect spikes of disease and employ PFGE molecular typing for E. coli and non-typhoidal salmonella (PulseNet) ${ }^{148,156-159}$. Other federal programs included the Public Health Laboratory Information System (PHLIS), the 1991 National Electronic Telecommunications System for Surveillance (NETSS) for the communication of weekly state reports on notifiable disease, and the Tuberculosis Genotyping Network. Integration efforts were coordinated by the Health Information Surveillance System (HISS) Board (est. 1995). In some states, the introduction of electronic reporting reduced disease reporting from 35 days to 24 hours but this was sporadic $^{160}$. The US also explored possibilities of strengthening international and hemispheric disease surveillance ${ }^{161}$. However, it remained unclear whether more efficient networks could compensate for growing personnel gaps in the US surveillance infrastructure.

Germany once again diverged from Anglo-American trends. Politicians also tried to contain rising health expenditure and introduce elements of "manacled competition"162. However, the decentralised nature of public health prevented overly ambitious budget cuts and reforms. Meanwhile, federal and state politicians faced growing pressure to upgrade existing arrangements in view of WHO priority health goals, the population-health oriented 1986 Ottawa Charter, and German reunification in $1990^{87,163}$. Although many components of East Germany's health system were subsequently decentralised, parts of its former public health infrastructure like the Institute for Experimental Epidemiology in Wernigerode were incorporated into the RKI. In Berlin, health politics received new prominence with the separation of the Federal Ministry of Health (Bundesgesundheitsministerium) from the Federal 
Ministry of Youth, Family, Women, and Health in 1991. Below the federal level, an increasing number of German states adopted new statutory principles for public health and rationalised service provision at the communal level ${ }^{87}$. As a result of interstate collaboration, long-standing recruitment problems were partially eased by no longer making public health an exclusively medical speciality and introducing postgraduate university courses ${ }^{164}$.

There were also significant reforms of German infectious disease control. In 1987, West Germany had launched an Immediate Action Programme to Combat HIV/AIDS, which created ca. 700 specialist positions in public health offices throughout the country. However, HIV protection remained patchy. In 1993, the German public was shocked to learn that around 2,000 haemophiliacs and 600 transfusion recipients had contracted HIV due to contaminated blood and blood products ${ }^{133}$. Although concerns about contaminated transfusions dated back to 1983 , the Bundesgesundheitsamt and state officials had failed to halt the distribution of untested HIVcontaminated products by a company called UB Plasma until October $1993^{165,166}$. The HIV scandal and concerns about other threats like multi-drug resistant and emerging diseases prompted a wider review of German disease control.

In 1994, the 118-year-old Bundesgesundheitsamt was dissolved. Its powers were distributed to the Federal Institute for Drugs and Medical Devices (Paul Ehrlich Institut), the Federal Institute for Consumer Protection (Bundesamt für Verbraucherschutz und Lebensmittelsicherheit), and the RKI, which also incorporated Germany's AIDS Centre and Institute of Social Medicine and Epidemiology ${ }^{166,167}$. In response to calls for improved disease surveillance, the RKI established the first federal network of reference and consultant laboratories in $1995^{168}$. Comprising 59 laboratories by 2015, the network spanned universities, federal and state laboratories, and private institutes and received financial support from the RKI. Members assumed responsibility for developing diagnostics, typing pathogens, maintaining reference strains, engaging in training and quality assurance, collaborating with 
international partners, and detecting outbreaks. Emulating long-standing Anglo-American reporting practices, the RKI also began issuing a weekly epidemiological bulletin, formed a Committee for Infectious Disease Epidemiology, updated nosocomial infection guidelines, and established outbreak response training ${ }^{133,169,170}$. In 1998, it published the first German Health Survey ${ }^{91,163,164}$. In the same year, new EU guidelines also triggered interparty drafting of an ambitious reordering of Germany's infectious disease legislation (see Part Four of this article) $)^{171}$.

After four decades of relative neglect, the combined effects of the reunification, scandals, and EU integration made decision-makers commit to strengthening and integrating Germany's decentralised Hinterland of ca. 360 state and communal Gesundheitsämter ${ }^{91}$. With public health and prevention expenditure making up a stable percentage of rising total health expenditure, there was also more money in the system ${ }^{87}$. Resulting reforms' focus on an integrated strengthening of communal, state, and federal-level public health was not because of planners' greater wisdom but because aggressive centralisation would have been resisted by states. German investment contrasted with declining Anglo-American public health capacity. Although the CDC and PHLS remained global leaders, there was increasingly little to fall back on should experts in Colindale or Atlanta fail to contain emerging outbreaks. 


\section{Part Four: The age of preparedness: 1999-2020}

Concerns about the functionality of public health systems acquired new urgency as a result of the 2001 anthrax attacks and the 2003 SARS-CoV outbreak. Large-scale reforms occurred in each analysed country. Effects were uneven. Injections of public money, public health reforms, and new IT and genomic technologies boosted the preparedness of authorities and their ability to quickly identify and react to outbreaks. However, overly ambitious rationalisation and shortlived funding surges often failed to sustainably strengthen public health infrastructures.

In Britain, the decade between 2003 and 2013 saw the biggest shakeups of infectious disease surveillance since the creation of the EPHLS in 1939. The first shake-up was the result of the Blair Administration's attempt to reform British health, social care, and consumer protection whilst also devolving powers to the national governments of Wales, Northern Ireland, and Scotland. In the wake of the 1996 mad cow disease (BSE) crisis, a new Food Standards Agency (est. 2000) was placed in charge of monitoring the food chain. One year later, the Department for Environment, Food and Rural Affairs (DEFRA) assumed responsibility for agriculture and environmental health and the creation of 303 NHS Primary Care Trusts (PCTs) led to a significant restructuring of community-level public health. PCTs were tasked with providing and commissioning primary, community, and secondary health services. Their creation fragmented the post-1988 arrangement of local infectious disease coordination between local authorities, CCDCs, DPHs, and the PHLS. Trying to counteract an ensuing dispersal of the existing NHS public health work force as well as PCTs' tendency to prioritise social and primary over public health services, the government provided ring-fenced budgets for community health until $2005^{52}$.

The PHLS did not escape reformism. In 2003, it was disbanded and merged into a new Health Protection Agency (HPA). The HPA was the brainchild of CMO Liam Donaldson and his 2002 Getting Ahead of the Curve report ${ }^{172}$. Referring to the 2001 US anthrax attacks, Donaldson's report painted a dark picture of the threat posed by new and emerging diseases as 
well as by chemical and nuclear hazards. In the case of infectious disease, it acknowledged successful PHLS surveillance but called for an integration of all aspects of health protection (infectious disease, chemical, and radiation hazards). While Acheson's CCDCs and DPHs had improved public health integration, they lacked formal powers and been weakened by the creation of PCTs and the abolishment of NHS regional health authorities. There were also reports about lacking standardisation of management, reporting, and biosecurity criteria in England's microbiology laboratories. In view of these problems, Donaldson's report recommended creating a new integrated national infection control and health protection agency that combined responsibility for all aspects of public health, integrated monitoring for human, environmental, and animal disease, and strengthened health protection alongside PCTs ${ }^{172}$.

In the case of the PHLS, this meant ending 64 years of integrated local and national infectious disease surveillance and transferring control of all local PHLS laboratories to the NHS - thereby implementing the 1985 DHSS recommendations. Rather than running its own network of local laboratories, the HPA would survey disease and provide specialist testing in its regional centres. It would coordinate with and commission additional testing from local microbiology services now being provided by the NHS Pathology Services in England. It was hoped that boosting the remit of the NHS Pathology Services would improve diagnostic, assurance, and reporting standards and that NHS PCTs, Strategic Health Authorities, and laboratories would support the HPA during outbreaks and devote sufficient resources towards preparedness and routine surveillance ${ }^{52,172}$.

The HPA was formally established on April 1 $1^{\text {st }}, 2003$ with four bases at Colindale, Porton Down ${ }^{\mathrm{iii}}$, Chilton, and South Mimms. It comprised a health protection services division, which would integrate a laboratory and a new national epidemiology service, a microbiology

iii The Centre for Applied Microbiology and Research (CAMR) at Porton Down had already been part of the PHLS between 1979 and 1994. 
services division, a centre for radiation, chemical and environmental hazards, and a division for biological standards and control ${ }^{173}$. Its regional Microbiology Network comprised only eight laboratories while the former PHLS' 37 hospital laboratories were transferred to the NHS. To facilitate laboratories' merger into the NHS without compromising public health surveillance, the government guaranteed a stable budget until April 2005 after which money would come from the NHS or direct HPA commissioning ${ }^{52}$. While it would no longer be as present as the PHLS had been, the HPA did not completely disappear from the local level either. The Agency's Health Protection Units (HPUs) were based across the country and were supposed to act as the "eyes and ears" of the HPA, liaise with local and NHS authorities, respond to health protection incidents, and keep "a finger on the health protection pulse locally"219.

Occurring parallel to the 2003 SARS-CoV outbreak, the creation of the HPA was greeted with mixed feelings by PHLS staff ${ }^{173}$. Giving evidence to the House of Lords, PHLS authorities repeated Howie's 1985 warnings about lacking incentives for NHS PCTs to provide adequate funding for nationally integrated public health monitoring:

There is real and general concern about the capacity to deliver enhanced surveillance or to mount an acute response. (...). There appear to be no plans as yet for providing any material incentive for NHS laboratories to rise to the public health challenge, and a fear that in local tussles about funding, money will be diverted from public health purposes $^{174}$.

It was also unclear whether HPA management would neglect infectious disease over other chemical or radioactive threats ${ }^{173}$. Reflecting on what had been an essentially PHLS-led SARS response $^{175}$, virologist Philip Mortimer warned that the UK had been lucky and that over relying on modelling and a slimmed down public health infrastructure of laboratories, contact tracers, and hospital isolation beds might prove costly during future outbreaks:

...it should not be assumed that a recurrence of SARS is therefore unlikely, or that a further outbreak would be controllable. (...). If there are weaknesses or deficiencies it should not be thought that they can or should be repaired by quick fixes each time an acute threat materialises. Such expenditures fail to build the infrastructure needed to maintain a comprehensive capacity for rapid and technologically appropriate response 
to new pathogens, and over time they distort facilities and so hinder the effective management of the laboratory ${ }^{176}$.

Mortimer's warnings proved prescient. Later remembered as a "painful birth", the first years of the HPA were characterised by a slow merging of once independent institutions. In contrast to Donaldson's vision of a "customer-focussed"173 and fully integrated public health service $^{\text {iv }}$, relations within the HPA were described as "territorial", which "led to a lot of wasted energy on positioning small politics and defending them"173. Coordinating HPA and NHS services was equally challenging. In the case of infectious disease surveillance, low staff morale, recruitment problems, and underinvestment in NHS microbiology services meant that maintaining effective collaborations between regional HPA hubs and local NHS laboratories could prove difficult ${ }^{138}$. A 2006 review of NHS Pathology Services in England also found that it was not obvious what kind of accountability a local NHS Trust had for providing public health microbiology services ${ }^{218}$.

At the community level, the abolishment of local health authorities and erosion of initially ring-fenced public health budgets undermined the provision of public health services. Problems were compounded by confused responsibilities. PCTs were charged with protecting community public health but relied on professionals in the HPA's headquarters and health protection units for response management. Local authorities were responsible for protecting the public from infectious disease and appointing a CCDC. However, CCDCs were no longer responsible to the NHS DPH but were employed by the HPA as part of its health protection units. Meanwhile, the HPA was dependent on PCTs, NHS Pathology Services, and local authorities for many aspects of routine surveillance and for detecting and mounting outbreak responses $^{52}$. At the national level, the HPA's post-2005 status as a non-departmental authority

iv In Wales, former PHLS services were integrated with local public health functions provided by Consultants for Communicable Disease Control. The new locally rooted service became the National Public Health Service for Wales and worked closely with NHS microbiology labs [138]. 
also risked creating dysfunctional parallel hierarchies with the NHS and Department of Health during public health emergencies ${ }^{173}$.

The 2008 financial crash exacerbated problems by reducing HPA funding. Between 2009 and 2013, HPA staffing decreased from 4,100 to 3,700. Meanwhile, the agency's core budget declined by over $26 \%$ from $£ 193$ million (2009/2010) to $£ 142$ million (2012/2013). Despite misgivings by some former PHLS members, the HPA became increasingly dependent on extramural grants and private funding for special programs and research, which could distort management priorities and create funding gaps for less lucrative programs ${ }^{173}$.

In 2010, the new Conservative government launched a policy of fiscal austerity. Despite successful HPA responses to the 2006 polonium killings and $2009 \mathrm{H} 1 \mathrm{~N} 1$ pandemic $^{173}$, a further streamlining and reorganization of public health was decided in 2011. In 2013, the HPA and its eight regional laboratories were integrated into Public Health England (PHE). The goal was to create a stream-lined public health service, which would merge over 5,000 staff from 129 organizations. In contrast to the HPA, PHE was an executive agency under direct control of the Department of Health and would be managed by a chief executive officer with no formal training in medicine or public health. Although PHE was supposed to be free to publish and speak on issues relating to the nation's health, the extent of this freedom was unclear ${ }^{177,220}$.

The creation of PHE was part of the second shakeup of British health care within a decade. The 2012 Health and Social Care Act abolished PCTs and stripped the NHS of its responsibility for local public health services, which were returned to local authorities. According to the new doctrine of democratic localism ${ }^{103}$, upper tier (county councils) and unitary (metropolitan) local authorities in England would once again establish multi-party Health and Wellbeing Boards (HWBs) and appoint a Director of Public Health (DPH) for the combined delivery of public health, health, and social services. Select primary care services such as screening, immunization, and public health services for children and pregnancy 
remained part of the NHS and were coordinated by Clinical Commissioning Groups (CCGs) and NHS England ${ }^{103,178}$. PHE and its health protection teams would monitor public health at the regional and national level, support service delivery by local and NHS authorities, and provide additional services like cost-effectiveness reviews, global health planning, and managing disease registries. Integration would be helped by the 2010 Health Protection Act, which had updated disease and other health hazard reporting requirements and given local authorities more flexible powers to deal with emergencies ${ }^{220-21}$.

(Re)-implementing effective localism proved challenging. The 2012 shake-up once again triggered retirements of experienced public health staff. Together with recruitment problems, this left $17 \%$ of Director of Public Health posts vacant in $2017^{178}$. To maintain effective preparedness and public health services in England, PHE relied on close collaboration with and support from the NHS and local authorities. Support included routine surveillance and reporting by NHS Pathology Services as well as the ability and willingness of local authorities and NHS managers to invest in and adhere to public health outcome frameworks ${ }^{173}$. Austerity and further cuts to NHS and council budgets made this difficult. Ministers had initially promised to ring-fence the public health budget for local authorities until 2016. However, an in-year cut of $£ 200$ million in 2015 was followed by a further $9.6 \%$ cut over the next five years. This amounted to a real term reduction of public health spending from $£ 3.5$ billion in 2015-2016 to just over $£ 3$ billion in 2020-2021 (a reduction from ca. $4.1 \%$ to $2.5 \%$ of total health expenditure) $)^{\mathrm{v}}$. PHE itself had to absorb a 30\% funding cut between 2013 and 2017. Funding shortages at the local level were exacerbated by 'top slicing' whereby councils reallocated ring-fenced public health budgets to other local services impacting health ${ }^{178,181,220}$.

\footnotetext{
${ }^{v}$ Other estimates speak of an even more dramatic reduction of $£ 700-850$ million in net expenditure between 2014/2015 and 2019/2020 with the poorest areas in England experiencing disproportionately high cuts of almost 15 percent. [179, 180].
} 
Ahead of the biggest pandemic event since 1918, public health capacity in England was compromised.

England's growing centre-hinterland discrepancy was mirrored in the US. Between 1999 and 2020, a brief effervescence of public health funding and reform was followed by a prolonged phase of stagnating budgets and capacity problems. In 1999, the Government Accountability Office (GAO) reported ongoing gaps in US disease surveillance and reporting. It remained voluntary for states to adopt the annually reviewed list of notifiable diseases issued by the CDC and Council of State and Territorial Epidemiologists. While this arrangement enabled states to opt out of expensive surveillance for diseases that were rare in their territory, it also created surveillance gaps for hepatitis $\mathrm{C}$ and $\mathrm{AMR}^{62,160}$. Technology differences increased gaps. In 1999, slightly more than half of state laboratories conducted PFGE-typing, 40 percent did not or barely used computerized systems to receive surveillance data, and 21 percent barely made use of computerized systems to transmit data ${ }^{160}$. Concerns were also raised about the commercialisation of public testing and patchy disease reporting by out-of-state laboratories ${ }^{160}$. Over 30 state laboratory directors warned that fee-based genetic screening and tests for regulatory and licensure programs were skewing laboratory operations "away from testing services beneficial to the entire community [like influenza surveillance]..."160. According to the GAO, there was a worrying lack of consensus on minimum public health surveillance capabilities ${ }^{160}$.

In response, the CDC outlined ways to improve US public health. According to the CDC, Americans were "a Nation at risk" 182 . The US was unprepared for new threats posed by the rapid dissemination of disease via global travel, rising AMR, and bioterrorism. Preparedness could, however, be improved with a new CDC Health Alert Network and by setting out regularly reviewed state improvement plans. Essentially repeating recommendations from the 1988 and 1992 IoM reports, the CDC announced that it would 
support states with extramural grants, training, technical assistance, and evaluations. Further recommendations centred on updating public health education, creating integrated data systems, and improving laboratory capabilities in all health departments ${ }^{182}$. In a second report from 2000, the CDC announced the creation of a laboratory response network and strategic plan for bioterrorism by $2004^{183}$. The APHL and Congress also announced measures to strengthen US public health infrastructures by $2010^{184,185}$.

Pressure to reform public health accelerated after the 2001 World Trade Centre and anthrax letter attacks. According to the IoM, both events had revealed:

...vulnerable and outdated health information systems and technologies, an insufficient and inadequately trained public health workforce, antiquated laboratory capacity, a lack of real-time surveillance and epidemiological systems, ineffective and fragmented communications networks, incomplete domestic preparedness and emergency response capabilities, and communities without access to essential public health services ${ }^{186}$.

During fiscal year 2002, the Bush Administration increased already rising federal preparedness spending ${ }^{187}$. Of the $\$ 2.9$ billion bioterrorism appropriations bill signed on January 10,2002 , $\$ 1.1$ billion were dedicated to upgrading bioterrorism preparedness, infectious-disease surveillance, network integration, and hospital surge capacity ${ }^{187}$. The CDC and APHL responded by identifying core functions and capabilities of public health laboratories and by establishing a dedicated Laboratory System Improvement Program (L-SIP). Regulators also developed a Model State Emergency Health Powers Act that could be implemented by states to better integrate inter-state emergency responses ${ }^{184,188-190}$.

Reforms and the surge of post-9/11 funding led to a brief flourishing of US public health. Many of the ca. 2,000 public health laboratories upgraded equipment, invested in 24/7 availability and IT networks, hired staff, and began offering molecular typing services ${ }^{187,191}$. At the federal level, the CDC expanded the National Antimicrobial Resistance Monitoring System (NARMS), VetNet for salmonella in animals, FoodNet for the surveillance of foodborne diseases, and OutbreakNet for PFGE data sharing ${ }^{192}$. CDC officials also collaborated with the FDA and the new Department of Homeland Security (DHS) to create the 
Food Emergency Response Network (FERN, 2004) and Environmental Public Health Tracking Network (EPHT, 2005) and to improve federal emergency coordination ${ }^{193}$. In 2003, US public health authorities used their new resources to mount an effective response to $\mathrm{SARS}^{187}$ although the CDC subsequently highlighted the need for additional local testing capacity ${ }^{194}$. In 2006, the Pandemic and All-Hazards Preparedness Act (PAHPA) and creation of the Biomedical Advanced Research and Development Authority (BARDA) further enhanced authorities' ability to prepare for emergencies with strategic stockpiles and research on potential biological, chemical, and nuclear threats ${ }^{187}$.

Many commentators, however, warned that a brief surge of funding would be insufficient to sustainably restore US public health capacity. Warnings went unheard. Preparedness funding peaked in $2004^{195}$. At the federal level, there were growing tensions between DHS and CDC over where federal money should be invested, how much should be narrowly earmarked for bioterrorism preparedness, and how information flows should be handled ${ }^{187}$. Although states and counties had used federal preparedness funds to upgrade public health systems, many complained about planning uncertainty and that bioterrorism scenarios were draining resources from routine surveillance ${ }^{187}$. The relative neglect of standard public health programs was exacerbated by the Bush Administration's decision to slash the federal budget for preventing chronic disease, promoting health, and controlling infectious disease by $\$ 67$ million and imposed flat spending on other programs ${ }^{187}$. Between 2003 and 2004, statelevel fiscal problems, delayed federal pay outs, and increased expenditure on Medicaid and Medicare programs resulted in public health budget declines in more than half of US states ${ }^{187}$. According to a 2008 survey of state public health laboratories, $64 \%$ had insufficient staff levels, many could not afford regular training, and $43 \%$ remained unable to mandate the submission of isolates and specimens from commercial laboratories ${ }^{192,196}$. 
Despite these problems, the US mounted an effective response to the $2009 \mathrm{H} 1 \mathrm{~N} 1$ pandemic. New molecular capabilities meant that it took only two weeks from the identification of the novel virus to the creation, emergency FDA authorization, manufacture, and distribution of a rapid RT-PCR-based test. Rapid FDA licensing had in part been possible because of prior CDC and BARDA investment in a platform technology (five target assay) for rapid influenza testing that could be quickly modified. The US had also stockpiled reagents ${ }^{197}$. Within a few days of modifying the test, representatives from 44 public health laboratories had visited the CDC for training. Although false negatives resulting from less accurate rapid tests caused problems, PCR-based testing and vaccine development bolstered confidence in US pandemic preparedness $^{197}$.

Looking back at the H1N1 response, the APHL highlighted the importance of preparedness research and genomic technologies for future pandemics:

Before [H1N1], the federal government would have to make a lot of tests, and we'd send them out, and people would use them ... With people being able to do their own PCR, we could put up the recipe and let people make that themselves. It's a much more robust approach for people able to ramp up testing for a novel pathogen ${ }^{197}$.

Despite concerns about substandard testing and profiteering, the fact that academic, private, and clinical laboratories could validate 'homebrew' tests against a published reproducible gold standard had stopped public health laboratories from being overwhelmed by a flood of specimens ${ }^{197}$. In addition to genomic technologies, sufficient public health laboratory personnel and adequate training were deemed equally critical for future preparedness ${ }^{197}$.

Similar to the UK, the 2008 financial crash and ensuing fiscal crisis threatened this human aspect of preparedness. With US states facing severe pressure, public health laboratories were forced to reduce or commercialise testing services. In 2009, most of the Obama Administration's $\$ 5.8$ billion of $\mathrm{H} 1 \mathrm{~N} 1$ surge funding was spent on vaccination and only a small percentage of funds reached laboratories ${ }^{197}$. Between 2008 and 2010, over 44,000 jobs were lost in state and local health departments including public health physicians, laboratory 
specialists, and epidemiologists ${ }^{195}$. Staff shortages compromised surveillance. In 2010, 24 percent of US states could not submit 90 percent of E. coli molecular typing results to CDC's PulseNet database within 4 working days ${ }^{195}$. Meanwhile, porous accreditation frameworks continued to impede quality assurance and data sharing between private and public laboratories and between local, state, and federal agencies ${ }^{198,199, v i}$.

Challenges for public health laboratories increased following the enactment of the Obama Administration's 2010 Affordable Health Care Act. Medicare and Medicaid had been the source of significant revenue for public health laboratories. However, the vast increase of people eligible for basic testing necessitated both a significant upgrade of public billing systems and increased competition with commercial laboratories - with state laboratories still required to maintain core functions and provide services to uninsured Americans ${ }^{201-203}$. The 2012 decision to reallocate $\$ 6.25$ billion of the originally promised $\$ 15$ billion boost to public health and subsequent sequestrations further increased fiscal pressure on public laboratories. After briefly rising to ca. 3.18 percent of total health spending in 2002, US expenditure on public health declined to ca. 2.65 percent of total health spending in 2014 with a further fall to 2.4 percent predicted by $2023^{204}$. Although CDC planners tried to improve the efficiency and integration of existing networks with improved IT and next generation sequencing ${ }^{205,206}$, ongoing recruitment problems ${ }^{207}$ and public health budget cuts - including President Trump's announcement on February $10^{\text {th }}, 2020$ of a 16 percent reduction of CDC funding $204,208,209$ severely undermined US public health capabilities.

Of the three analysed countries, Germany was the only one to mostly strengthen public health between 2000 and 2020. Driven by new EU requirements, a new infectious disease law (Seuchenrechtsneuordnungsgesetz) replaced older legislation in 2001. Key public health

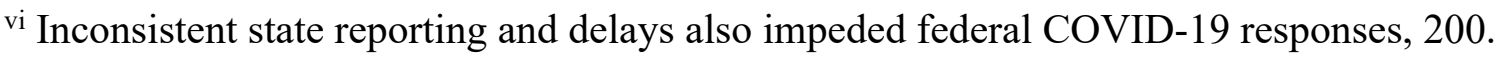
Tracking COVID-19 in the United States. From Information Catastrophe to Empowered Communities: Vital Strategies - Resolve to Save Lives, 2020.
} 
competences remained in the hand of state and communal authorities, but the 2001 law enhanced authorities' ability to respond to outbreaks with improved vaccination, surveillance, and police powers - including the right to impose quarantine and job bans. Berlin was empowered to impose federal control in the case of disease events of national significance. State-level and federal disease reporting requirements were unified and upgraded with the federal centre now able to demand surveillance data that included personal information during emergencies $^{87,210-212}$.

As the federal epidemiological centre, the RKI focused more resources on curbing nosocomial infections, increasing vaccine coverage (by incorporating Germany's permanent vaccine commission), and improving infectious disease surveillance and containment ${ }^{164}$. The RKI directed sentinel monitoring for specific diseases. Meanwhile, doctors, hospitals, and laboratories were required to report both suspected and confirmed reports of notifiable diseases to communal or state health authorities, who would then communicate routine information to the RKI in an anonymised form ${ }^{213}$. To facilitate data integration, the RKI rolled out SurvNet@RKI as the first integrated German electronic reporting platform for infectious disease among civilian authorities on January $1^{\text {st }}, 2001$ - and in the armed forces in $2006^{214}$. Following WHO guidance from 1999, Germany adopted its first pandemic plan in 2005. Centralised reporting systems were updated after the 2011 EHEC epidemic exposed ongoing communication gaps. A new electronic notification system (Deutsches Elektronisches Meldeund Informationssystem für den Infektionsschutz (DEMIS)) was trialled between 2016 and $2020^{210}$.

Repeatedly upgraded after 2001, Germany's new infectious disease legislation addressed long-standing organisational constraints at the communal and state level whilst also integrating national networks and strengthening federal oversight. This did not mean that variations in state public health arrangements ceased or that the RKI in Berlin became 
dominant. A further attempt to rationalise regulations and competencies was rejected by states in $2005^{164,211}$. The 2001 reform instead solved long-standing problems of fragmented responsibility, lacking integration, and political neglect. While English reforms were not accompanied by sufficient investment in local public health and US surge funding proved transient, German state, federal, and health insurance spending on prevention and public health services amounted to 3.27-3.52 percent of rising total health expenditure between 2000 and 2015. Money was spent both in the federal centre and on state and communal public health infrastructure ${ }^{87}$. While the RKI's international influence could not match that of the CDC, German authorities had managed to integrate public health whilst maintaining an intact public health hinterland with sufficient power to react flexibly should the centre be overwhelmed. 


\section{Conclusion: Reviving the Hinterland}

On the eve of COVID-19, assessing pandemic preparedness was deceptive: Anglo-American infectious disease hubs still wielded significant influence, had developed sophisticated IT and molecular typing infrastructures to link remaining assets, and could rapidly deploy experts and stockpiled equipment to quell localised outbreaks. Responses to the 2003 SARS, 2009 H1N1, and 2015 Ebola outbreaks had moreover shown that Anglo-American public health systems could protect citizens from limited foreign introductions of new or familiar pathogens.

However, beyond the centre, the decades after 1980 had seen local public health capacity for testing and contact tracing erode. Once the centre was overwhelmed, there was little hinterland capacity to flexibly protect the public's health. These weaknesses were well-known, had been highlighted by numerous commentators, and revealed by preparedness exercises like the UK's 2016 Operation Cygnus on pandemic flu ${ }^{215}$. However, they were not addressed by political decision makers or sufficiently taken account of by international performance reviews.

Conducted between 2018 and 2019, major global preparedness surveys by the World Bank, WHO, and Global Health Security Index focused on adherence to international norms - which had been historically defined by CDC and PHE experts -, rapid pathogen detection, reporting, and response capabilities, as well as health systems' capacity to treat sick workers. In the case of the Global Health Index, the report was moreover drafted by a team composed largely of Anglo-American experts and based in the US. The US and UK did very well in resulting rankings ${ }^{10,216-217}$. Experts, however, failed to acknowledge that in both countries local public health workers increasingly lacked bread-and-butter capabilities like integrated contact tracing and testing. Both would prove critical during the COVID-19 pandemic. By overemphasizing the capabilities of Colindale and Atlanta, global reviews compounded political neglect of the hinterland and helped create a false sense of security regarding actual preparedness. 
By contrast, Germany with its communal tradition of public health and relative tolerance of autonomous decision-making at different administrative levels was able to react dynamically with locally tailored public and private sector approaches to testing and contact tracing. Fragmentation was avoided as a result of the post-1994 strengthening of federal health and the RKI and because of the 2001 infectious disease law, which enabled the RKI to coordinate state and communal responses and send experts to aid individual outbreak responses. It is telling that other much poorer countries with strong local public health capabilities like Cuba and Vietnam were also able to launch effective public health responses using traditional methods like to door-to-door testing and localised lockdowns ${ }^{12}$.

Casting a stark light on recent preparedness estimates and successive administrations' neglect of public health, the divergence of global responses to COVID-19 highlights that the strength of a public health system depends as much on technology and coordination as it does on sustained investment in human capacity in the hinterland. Ensuring that this capacity is rebuilt, sustainably maintained, and regularly audited will be a major challenge for the postpandemic era. Doing so will entail different reforms in different countries. Transplanting systems will not work. Decision-makers will have to take account of existing strengths as well as varying constitutional formats and political values. Of similar importance is having the political courage to give public health institutions sufficient autonomy to act as effective advocates for public health and resisting the urge to reformat existing systems every decade. 


\section{Bibliography}

1. Andersen KG, Rambaut A, Lipkin WI, et al. The proximal origin of SARS-CoV-2. Nature medicine 2020;26(4):450-52.

2. Peeri NC, Shrestha N, Rahman MS, et al. The SARS, MERS and novel coronavirus (COVID-19) epidemics, the newest and biggest global health threats: what lessons have we learned? International journal of epidemiology 2020

3. Huang C, Wang Y, Li X, et al. Clinical features of patients infected with 2019 novel coronavirus in Wuhan, China. The Lancet 2020;395(10223):497-506.

4. WHO. Archived: WHO-Timeline of COVID-19 2020 [Available from: https:/www.who.int/news-room/detail/27-04-2020-who-timeline---covid-19.]

5. Deslandes A, Berti V, Tandjaoui-Lambotte Y, et al. SARS-COV-2 was already spreading in France in late December 2019. International Journal of Antimicrobial Agents 2020:106006.

6. La Rosa G, Mancini P, Ferraro GB, et al. SARS-CoV-2 has been circulating in northern Italy since December 2019: evidence from environmental monitoring. medRxiv 2020

7. WHO Director General's opening remarks at the media briefing on COVID-19 - 16 March 2020: World Health Organisation, 2020.

8. Keck F. Avian Reservoirs: Virus Hunters and Birdwatchers in Chinese Sentinel Posts: Duke University Press 2020.

9. Lee YN. These Asian economies seem to have contained the coronavirus outbreak. 2020.

10. Global health Security Index. Building Collective Action and Accountability: NTI/ Johns Hopkins Bloomberg School of Public Health, 2019.

11. Fukuyama F. The Pandemic and Political Order. It Takes a State. Foreign Affairs 2020 (July/August)

12. Crosby S, Dieleman JL, Kiernan S, et al. All Bets are off for measuring pandemic preparedness. Think Global Health 2020 30.06.2020

https://www.thinkglobalhealth.org/article/all-bets-are-measuring-pandemicpreparedness.

13. Lipton E, Goodnough A, Shear MD, et al. The C.D.C. Waited 'Its Entire Existence for This Moment.' What Went Wrong? New York Times 2020 03.06.2020.

14. Helm T, Graham-Harrison E, McKie R. How did Britain get its coronavirus response so wrong? Guardian 2020 19.04.2020.

15. Graf A. Was Tests für alle wirklich bringen würden. Zeit Online 2020 30.08.2020.

16. Wieler L, Rexroth U, Gottschalk R. Emerging COVID-19 success story: Germany's strong enabling environment. Our World in Data 2020 [published Online First: 30.06.2020]

17. Pybus O, Rambaut AR, Plessis Ld, et al. Preliminary analysis of SARS-CoV-2 importation \& establishment of UK transmission lineages. Virologyorg 2020 09.06.2020. https://virological.org/t/preliminary-analysis-of-sars-cov-2-importationestablishment-of-uk-transmission-lineages/507\#footnote1.

18. Clark P, Cookson C, Hughes, L. How the UK got coronavirus testing wrong. Financial Times 2020 27.03.2020.

19. Trump DJ. Proclamation on Declaring a National Emergency Concerning the Novel Coronavirus Disease (COVID-19) Outbreak. White House, 2020 13.03.2020.

20. COVID C, Jorden MA, Rudman SL, et al. Evidence for Limited Early Spread of COVID19 Within the United States, January-February 2020. MMWR Morbidity and mortality weekly report 2020;69(22):680-84.

21. Garside J. UK set to award Covid-19 testing contracts worth $£ 5$ bn to private bidders. Guardian 2020 02.07.2020. 
22. Weiner R. What is pool testing and how does it work? Washington Post 2020 27.06.2020.

23. Murphy S, Marsh S. UK government urged to justify $£ 108 \mathrm{~m}$ contact-tracing deal with Serco. Guardian 2020 11.08.2020.

24. Pollock A. Thanks to outsourcing, England's test and trace systems are in chaos. Guardian 2020 31.07.2020.

25. Campbell D, Walker P. Ministers shifting blame to Public Health England for Covid-19 errors, say experts. Guardian 2020 01.07.2020.

26. Grey S, ]Macaskill A, Mcneill R, et al. Into the fog: How Britain lost track of the coronavirus. Reuters 2020 29.06.2020.

27. Hope C. Hancock axes 'failing' Public Health England The Telegraph 2020 15.08.2020.

28. Hardy A. Salmonella Infections, Networks of Knowledge, and Public Health in Britain 1880-1975. Oxford: Oxford University Press 2015.

29. Harrison M. Disease and the Modern World. 1500 to the Present Day. Cambridge and Malden: Polity Press 2004.

30. Rosen G. From Medical Police to Social Medicine. Essays on the History of Health Care. New York: Science History Publications 1974.

31. Snowden FM. Emerging and reemerging diseases: a historical perspective. Immunological Reviews 2008;225:9-26.

32. Berridge V, Gorsky M, Mold A. Public health in history: McGraw-Hill Education (UK) 2011.

33. Vanderslott S, Phillips MT, Kirchhelle C. Water And Filth: Re-evaluating The First Era Of Sanitary Typhoid Intervention. Clinical Infectious Diseases 2019;69(5_1):S377S384.

34. Wall R. Bacteria in Britain, 1880-1939. London: Routledge 2013.

35. Chakrabarti P. Bacteriology in British India: Laboratory Medicine and the Tropics. Rochester, NY: University of Rochester Press 2012.

36. Harrison M. The Tender Frame of Man' - Disease, Climate, and Racial Difference in India and the West Indies, 1760-1860. Bulletin of the History of Medicine 1996;70(1):68-93.

37. Echenberg M. Plague ports: the global urban impact of bubonic plague, 1894-1901: NYU Press 2010.

38. Mendelsohn JA. From Eradication to Equilibrium: How Epidemics Became Complex after World War I. In: Lawrence CW, George, ed. Greater Than The Parts Holism in Biomedicine 1920-1950. Oxford and New York: Oxford University Press 1998:30331.

39. Mendelsohn JA. Cultures of Bacteriology: Formation and Transformation of a Science in France and Germany, 1870-1914. Princeton, 1996.

40. Méthot P-O. Bacterial Transformation and the Origins of Epidemics in the Interwar Period: The Epidemiological Significance of Fred Griffith's 'Transforming Experiment. Journal of the history of Biology 2016;49:311-58.

41. Wald P. Cultures and Carriers: 'Typhoid Mary' and the Science of Social Control. Social Text 1997;52/53:181-214.

42. Berger S. ,Die Jagd auf Mikrobien hat erheblich an Reiz verloren' - Der sinkende Stern der Bakteriologie in Medizin und Gesundheitspolitik der Weimarer Politik. In: Lengwiler M, Madarász J, eds. Bielefeld transcript Verlag 2010:87-114.

43. Berger S. Bakterien in Krieg und Frieden: Eine Geschichte der medizinischen Bakteriologie in Deutschland, 1890-1933. Göttingen: Wallstein Verlag 2009.

44. Amsterdamska O. Medical and Biological Constraints: Early Research on Variation in Bacteriology. Social Studies of Science 1987;17(4):657-87. 
45. Amsterdamska O. Stabilizing Instability: The Controversy over Cyclogenic Theories of Bacterial Variation during the Interwar Period. Journal of the History of Biology Summer 1991;24(2):191-222.

46. Gradmann C, Harrison M, Rasmussen A. Typhoid and the Military. Clinical Infectious Diseases 2019;69(5_1):S385-S387.

47. Davidson R. 'Searching for Mary, Glasgow': Contact Tracing for Sexually Transmitted Diseases in Twentieth-Century Scotland. Social history of medicine 1996;9(2):195214.

48. Mazumdar PMH. The State, the Serum Institutes and the League of Nations. In: Gradmann C, Simon J, eds. Evaluating and Standardizing Therapeutic Agents, 18901950. New York and Basingstoke: Palgrave Macmillan 2010:118-38.

49. Mazumdar PMH. In the Silence of the Laboratory: the League of Nations standardizes syphilis tests. Social History of Medicine 2003;16(3):437-59.

50. Kirchhelle C. The forgotten typers: the rise and fall of Weimar bacteriophage-typing (1921-1935). Notes and Records 2019

51. Wilson GS. Public Health Laboratory Service.-Part II. British medical journal 1948;1(4553):677.

52. Rowland D. Mapping Communicable Disease Control Administration In The UK. Between Devolution and Europe. London Nuffield Trust, 2006.

53. Williams REO. Microbiology for the Public Health. The Evolution of the Public Health Laboratory Service 1939-1980. London: Public Health Laboratory Service 1985.

54. Kirchhelle C, Dyson ZA, Dougan G. A Biohistorical Perspective of Typhoid and Antimicrobial Resistance. Clinical infectious diseases: an official publication of the Infectious Diseases Society of America 2019;69(Suppl 5):S388.

55. Sikorski MJ, Levine MM. Reviving the "Moore swab": a classic environmental surveillance tool involving filtration of flowing surface water and sewage water to recover typhoidal Salmonella. Applied and Environmental Microbiology 2020.

56. Williams GS, Atkinson JD. Typing Of Staphylococci By The Bacteriophage Method. Lancet 1945 ; 245(6352):647-48.

57. Hillier K. Babies and Bacteria: Phage Typing Bacteriologists, and the Birth of Infection Control. Bulletin of the History of Medicine 2006;80(4):733-61.

58. Condrau F, Kirk RGW. Negotiating hospital infections: The debate between ecological balance and eradication strategies in British hospitals, 1947-1969. Dynamis 2011;31(2):385-404.

59. Kirchhelle C. Swann Song. British antibiotic regulation in livestock production (19532006). Bulletin of the History of Medicine 2018;92(2):317-350.

60. Parker MT. Clinical Pathology In General Practice: The Public Health Laboratory Service. British Medical Journal 1953;2(4840):823-25.

61. Anon. Colindale. Hub of the Public Health Laboratory Service. The Lancet 1953:190-91.

62. Pollock G. Fevers and Cultures. Lessons for surveillance, prevention and control. Abingdon Radcliffe Medical Press 2003.

63. Control CfD, Prevention. Achievements in public health, 1900-1999: changes in the public health system. MMWR Morb Mortal Wkly Rep 1999;48(50):1141-7.

64. Valdiserri RO. Temples of the future: an historical overview of the laboratory's role in public health practice. Annual Review of Public Health 1993;14(1):635-48.

65. Thacker SB, Berkelman RL. Public health surveillance in the United States. Epidemiologic reviews 1988;10(1):164-90.

66. Medicine Io. The Future of Public Health. Committee for the Study of the Future of Public Health. Washington DC: Institute of Medicine, 1988. 
67. Farley J. To cast out disease: a history of the International Health Division of Rockefeller Foundation (1913-1951): Oxford University Press 2004.

68. Satcher D. The history of the public health service and the surgeon general's priorities. Food and drug law journal 1999;54(1):13-19.

69. Anonymous. Public Health Laboratories. JAMA 1916;66(17):1309-10.

70. Carpenter D. Reputation and Power. Organizational Image and Pharmaceutical Regulation at the FDA. Princeton and Oxford: Princeton University Press 2010.

71. CDC. Notifiable disease surveillance and notifiable disease statistics--United States, June 1946 and June 1996. MMWR Morbidity and mortality weekly report 1996;45(25):530.

72. Wyatt L. Intergovernmental Relations in Public Health: University of Minnesota Press 1951.

73. Wright Jr JR. The politics underlying the provision of and changes in pathology and laboratory services in the United States during the Roaring Twenties. Archives of pathology \& laboratory medicine 2016;140(9):983-91.

74. Leider JP, Resnick B, Bishai D, et al. How much do we spend? Creating historical estimates of public health expenditures in the United States at the federal, state, and local levels. Annual review of public health 2018;39:471-87.

75. Mountin JW, Flook EE. Distribution of health services in the structure of state government: US Government Printing Office 1947.

76. Etheridge EW. Sentinel for health: a history of the Centers for Disease Control: Univ of California Press 1992.

77. Kirchhelle C. Between Bacteriology and Toxicology - Agricultural Antibiotics and US Risk Regulation. In: Creager ANH, Gaudilliere J-P, eds. Risk on the Table New York: Berghahn Forthcoming (Jan 2021).

78. Tiffany EJ. Public Health and Clinical Laboratories in the Diagnosis of Enteric Bacterial Infections. Public Health Reports 1952;67(11):1069-75.

79. CDC. History of The National Communicable Disease Centre From 1963 to 1968. Atlanta Department of Health, Education, and Welfare - Public Health Service 1969.

80. CDC. History of CDC. MMWR Morbidity and mortality weekly report 1996;45(25):526.

81. Langmuir AD. The surveillance of communicable diseases of national importance. New England journal of medicine 1963;268(4):182-92.

82. Allerberger F. Strukturelle Voraussetzungen und Bedingungen für eine effektive mikrobiologische Diagnostik bei Ausbruchsgeschehen. BundesgesundheitsblattGesundheitsforschung-Gesundheitsschutz 2013;56(1):22-27.

83. Hulverscheidt M, Laukötter A. Infektion und Institution: Zur Wissenschaftsgeschichte des Robert Koch-Instituts im Nationalsozialismus: Wallstein Verlag 2013.

84. Hüntelmann AC. Biopolitische Netzwerke: Die interpersonellen und interinstitutionellen Verbindungen zwischen dem Institut für Infektionskrankheiten und dem Reichsgesundheitsamt vor 1935. In: Hulverscheidt M, Laukötter A, eds. Infektion und Institution Zur Wissenschaftsgeschichte des Robert Koch-Instituts im Nationalsozialismus. Göttingen: Wallstein Verlag 2009.

85. Hinz-Wessels A. Das RKI unter der NS-Diktatur. Personelle, administrative und inhaltliche Umgestaltung zwischen 1933 und 1945. In: Hulverscheidt M, Laukötter A, eds. Infektion und Institution Zur Wissenschaftsgeschigte des Robert Koch-Instituts im Nationalsozialismus. Göttingen: Wallstein Verlag 2009:67-88.

86. Neuhaus R, Schräder WF. Planning and management of public health in the Federal Republic of Germany. Health Policy 1985;5(2):99-109.

87. Plümer K, Rechel B, Maresso S, et al. Organization and financing of public health services in Europe: Country reports. Germany: Copenhagen: WHO Regional Office 
for Europe on behalf of the European Observatory on Health Systems and Policies 2018:35-48.

88. Lindner U. Gesundheitspolitik in der Nachkriegszeit: Grossbritannien und die Bundesrepublik Deutschland im Vergleich: Oldenbourg Verlag 2011.

89. Kohlrausch M, Krüger CG, Patel KK, et al. Wo liegt die Bundesrepublik?: Vergleichende Perspektiven auf die westdeutsche Geschichte: Vandenhoeck \& Ruprecht 2016.

90. Thießen M. Vorsorge als Ordnung des Sozialen: Impfen in der Bundesrepublik und der DDR. Zeithistorische Forschungen 2013;10:409-32.

91. Health Care Systems in Transition: Germany: European Observatory on Health Care Systems, 2000.

92. Harrison M. Contagion. How Commerce Has Spread Disease. New Haven and London: Yale University Press 2012.

93. Harrison M. Pandemics. In: Jackson M, ed. The Routledge History of Disease. Abingdon: Routledge 2017:129-46.

94. Packard R. A History of Global Health: Interventions into the Lives of Other Peoples. Baltimore: Johns Hopkins Press 2016.

95. Lengwiler M, Madarász J. Präventionsgeschichte als Kulturgeschichte der Gesundheitspolitik. In: Lengwiler M, Madarász J, eds. Das präventive Selbst Eine Kulturgeschichte moderner Gesundheitspolitik. Bielefeld transcript Verlag 2010:1128.

96. Lindner U. Sicherheits- und Präventionskonzepte im Umbruch: von der Gruppenvorsorge zur individualisierten medizinischen Risikoprävention für Schwangere. In: Lengwiler M, Madarász J, eds. Das präventive Selbst Eine Kulturgeschichte moderner Gesundheitspolitik. Bielefeld: transcript Verlag 2010:229-49.

97. Timmermann C. Risikofaktoren: Der scheinbar unaufhaltsame Erfolg eines Ansatzes aus der amerikanischen Epidemiologie in der deutschen Nachkriegsmedizin. In:

Lengwiler M, Madarász J, eds. Das präventive Selbst Eine Kulturgeschichte moderner Gesundheitspolitik. Bielefeld: transcript Verlag 2010:251-77.

98. Greene JA, Watkins ES. Introduction. In: Greene JA, Watkins ES, eds. Writing, Filing, Using, and Abusing the Prescription in Modern America. Baltimore: Johns Hopkins University Press 2012:1-22.

99. Ayliffe GAJ, English MP. Hospital Infection. From Miasmas to MRSA. Cambridge: Cambridge University Press 2003.

100. Gradmann C. From lighthouse to hothouse: hospital hygiene, antibiotics and the evolution of infectious disease, 1950-1990. History and Philosophy of the Life Sciences 2017;40(1):8.

101. Howie J. The Public Health Laboratory Service. The Lancet 1965;285(7384):501-05.

102. Public Health in England. The report of the Committee of Inquiry into the future development of the Public Health Function. London House of Commons, 1988.

103. Gorsky M, Lock K, Hogarth S. Public health and English local government: historical perspectives on the impact of 'returning home'. Journal of Public Health 2014;36(4):546-51.

104. Baggott R. Public Health. Policy and Politics. 2nd Edition ed. Houndsmill \& New York: Palgrave Macmillan 2000.

105. Edgar WM. Letters to the Editor: The Public Health Laboratory Service. Lancet 1965:599.

106. Warrack AJN. Clinical Pathology in General Practice. British Medical Journal 1953;2(4842):935.

107. Parker MT. Clincial Pathology in General Practice. British Medical Journal 1953;2(4844):1048. 
108. Clark P. 'Problems of Today and Tomorrow': Prevention and the National Health Service in the 1970s. Social History of Medicine 2020;33(3):981-1000.

109. Report of the Working Party on the Laboraotry use of Dangerous Pathogens. London Department of Helath and Social Security, 1975.

110. Report of the DHSS review of the Public Health Laboratory Service London Department of Health and Social Security, 1985.

111. Macfarlane JT, Worboys M. Showers, sweating and suing: Legionnaires' disease and 'new'infections in Britain, 1977-90. Medical history 2012;56(1):72-93.

112. Howie J. Threat to the PHLS. British medical journal (Clinical research ed) 1985;290(6468):579.

113. Turner G. Threat to the PHLS. British medical journal (Clinical research ed) 1985;290(6470):787.

114. Hughes RA. PHLS reform. Professional advisers' views over-ruled. British Medical Journal 1985;291:7.

115. Veitch A. Shake-up 'will harm disease detection'. Guardian 1985 08.03.1985.

116. Lords Sitting of Wednesday, 20th November, 1985.

117. Public Health Laboratory Service: 04.06.1985. House of Lords. London: Hansard, 1985.

118. Public Health Laboratory Service Policy Navigator: The Health Foundation; 2020 [Available from: https://navigator.health.org.uk/content/public-health-laboratoryservice accessed 09.07.2020 2020.]

119. Miller D. Risk, science and policy: definitional struggles, information management, the media and BSE. Social Science \& Medicine 1999;49(9):1239-55.

120. Schneider D, Evering-Watley M, Walke H, et al. Training the global public health workforce through applied epidemiology training programs: CDC's experience, 1951-2011. Public Health Reviews 2011;33(1):190-203.

121. Bhattacharya S. Reflections on the eradication of smallpox. The Lancet 2010;375(9726):1602-03.

122. Schmidt RM, Madoff MA. The state and territorial public health laboratory: program activities, organization and prospects for the future. American journal of public health 1977;67(5):433-38.

123. Consolidated Annual Report on State and Territorial Public Health Laboratories Fiscal Year 1982. Atlanta: HHS Publication, 1984.

124. Consolidated Annual Report On State \& Territorial Public Health Laboratories Fiscal year 1975. Atlanta: CDC, 1976.

125. Public Health Personnel in the United States, 1980. Washington HHS 1982.

126. Adcock D, Lawton $\mathrm{H}$. The paperwork crunch in state public health laboratories. American journal of public health 1981;71(7):748-50.

127. Berkelman RL, Freeman P. Emerging infections and the CDC Response. Emerging Illnesses and Society: Negotiating the Public Health Agenda Johns Hopkins University Press, Baltimore 2004:350-87.

128. Etheredge L. Reagan, Congress, and health spending. Health Affairs 1983;2(1):14-24.

129. Microscope on Washington. Laboratory Medicine 1982;13(2):76-77.

130. CDC Staffing for AIDS Programs. Washington DC: General Accounting Office, 1989.

131. Smith E. An overview of venereal disease programs in Britain, West Germany, Denmark, and Sweden, with implications for Canada. Bulletin of the Pan American Health Organization (PAHO) 1976;10(4):321-32.

132. Meyer-Hartwig K, Bleifeld W. Education and professional training of biomedical engineers in West Germany. Journal of medical engineering \& technology 1978;2(2):62-66. 
133. Frank U, Gastmeier P, Rüden H, et al. The organization of infection control in Germany. Journal of Hospital Infection 2001;49(1):9-13.

134. Hurst JW. Reform of health care in Germany. Health Care Financing Review 1991;12(3):73.

135. Reintjes R, Nolte E, Shamsul B, et al. Infectious diseases before and after German unification: Trends in mortality and morbidity. European journal of epidemiology 2001;17(12):1105-10.

136. Berridge V, Christie D, Tansey E. Public Health in the 1980s and 1990s: Decline and Rise?: Wellcome Trust Centre for the History of Medicine at UCL 2006.

137. Kisely S, Jones J. Acheson revisited: public health medicine ten years after the Acheson Report. Public health 1997;111(6):361-64.

138. Duerden B. Twenty-first-century medical microbiology services in the UK. Nature Reviews Microbiology 2005;3(12):979-83.

139. Lindner U. Die Krise des Wohlfahrtsstaats im Gesundheitssektor Bundesrepublik Deutschland, Großbritannien und Schweden. Archiv für Sozialgeschichte 2007;47:297.

140. Statement of Achievements. London: PHLS 1995.

141. Lahti CJ. Pulsed field gel electrophoresis in the clinical microbiology laboratory. Journal of clinical laboratory analysis 1996;10(6):326-30.

142. A Report of the Study of Infectious Intestinal Disease in England. London: Food Standards Agency/ Public Health Laboratory Service, 2000.

143. Verity C, Manning D, Nicoll A. Consent, confidentiality, and the threat to public health surveillanceCommentary: Don't waive consent lightly-involve the public. $B M J$ 2002;324(7347):1210-13.

144. Borriello S. Near patient microbiological tests. BMJ 1999;319(7205):298-301.

145. Kirchhelle C. Pyrrhic Progress: Antibiotics in Anglo-American Food Production (19492018). New Brunswick: Rutgers University Press 2020.

146. Pini P. PHLS celebrates Golden Jubilee. The Lancet 1996;348(9038):1371.

147. Emerging Infections. Microbial Threats to Health in the United States. Washington DC: Institute of Medicine, 1992.

148. Berkelman RL, Bryan RT, Osterholm MT, et al. Infectious disease surveillance: a crumbling foundation. Science 1994;264(5157):368-70.

149. Dowdle WR. The future of the public health laboratory. Annual review of public health 1993;14(1):649-64.

150. Fishman RU. What is APHA's future in public health? Journal of public health policy 1992;13(1):14-17.

151. Estimated expenditures for core public health functions--selected states, October 1992September 1993. MMWR Morbidity and mortality weekly report 1995;44(22):421, 27.

152. Estimated expenditures for essential public health services--selected states, fiscal year 1995. MMWR Morbidity and mortality weekly report 1997;46(7):150.

153. Felman YM, Corsaro MC, Jones JR. Laboratory compliance with syphilis reporting laws: the New York City experience 1972-77. Public Health Reports 1980;95(1):53.

154. Avery G. Outsourcing public health laboratory services: A blueprint for determining whether to privatize and how. Public Administration Review 2000;60(4):330-37.

155. Gebbie KM. Public Health. In: Nelson RR, ed. The Limits of Market Organisation. New York: Russell Sage Foundation 2005:321-34.

156. Roper WL, Baker Jr EL, Dyal WW, et al. Strengthening the public health system. Public Health Reports 1992;107(6):609.

157. Laboratory capacity to detect antimicrobial resistance, 1998. MMWR Morbidity and mortality weekly report 2000;48(51-52):1167. 
158. Tokars JI, Rudnick JR, Kroc K, et al. US hospital mycobacteriology laboratories: status and comparison with state public health department laboratories. Journal of Clinical Microbiology 1996;34(3):680-85.

159. Swaminathan B, Barrett TJ, Hunter SB, et al. PulseNet: the molecular subtyping network for foodborne bacterial disease surveillance, United States. Emerging Infectious Diseases 2001;7(3):382.

160. Steinhardt B. Emerging Infectious Diseases. Consensus on Needed Laboratory Capacity Could Strengthen Surveillance. Washington DC: General Accounting Office, 1999.

161. Epstein DB. Recommendations for a regional strategy for the prevention and control of emerging infectious diseases in the Americas. Emerging Infectious Diseases 1995;1(3):103.

162. Brown LD, Amelung VE. 'Manacled Competition': Market Reforms In German Health Care: Is managed competition really a new paradigm or simply a stalemated strategy? Recent German experience helps to answer this question. Health affairs 1999;18(3):76-91.

163. Riedmann K. Die historische Entwicklung der Gesundheitsberichterstattung in Deutschland. Bundesgesundheitsblatt-Gesundheitsforschung-Gesundheitsschutz 2000;43(8):594-99.

164. Busse R, Blümel M. Germany: Health System Review. Health System in Transition: European Observatory on Health Systems and Policies, 2014.

165. Weinberg PD, Hounshell J, Sherman LA, et al. Legal, financial, and public health consequences of HIV contamination of blood and blood products in the 1980s and 1990s. Annals of internal medicine 2002;136(4):312-19.

166. Zweite Beschlußempfehlung und Schlußbereicht des 3. Untersuchungsausschusses nach Artikel 44 des Grundgesetzes. Deutscher Bundestag 12. Wahlperiode. Bonn 1994.

167. Dressler S. Blood "scandal" and AIDS in Germany. Blood feuds: AIDS, blood, and the politics of medical disaster 1999:191-212.

168. Laude G, Kist M, Krause G. Etablierung von Referenznetzwerken aus Nationalen Referenzzentren mit assoziierten Konsiliarlaboratorien in Deutschland. Bundesgesundheitsblatt-Gesundheitsforschung-Gesundheitsschutz 2009;52(10):91926.

169. Beermann S, Allerberger F, Wirtz A, et al. Public health microbiology in Germany: 20 years of national reference centers and consultant laboratories. International Journal of Medical Microbiology 2015;305(7):595-600.

170. Petersen LR, Ammon A, Hamouda O, et al. Developing national epidemiologic capacity to meet the challenges of emerging infections in Germany. Emerging Infectious Diseases 2000;6(6):576.

171. Seuchenrecht Soll Neu Geordnet Werden (Gesetzentwurf). Deutscher Bundestag, 2000.

172. Donaldson L. Getting Ahead of the Curve. A strategy for combating infectious diseases (including other aspects of health protection). London, 2002.

173. The history of the Health Protection Agency 2003-2013. London Public Health England, 2013.

174. Memorandum by the Public Health Laboratory Service (PHLS). House of Lords Select Committee on Science and Technology. London HMSO, 2003.

175. Harper DR. Preparedness for SARS in the UK in 2003. Philosophical Transactions of the Royal Society of London Series B: Biological Sciences 2004;359(1447):1131-32.

176. Mortimer PP. Stray Thoughts on SARS. Communicable Disease and Public Health 2003;6(3):172-76.

177. Das P. Duncan Selbie: the new face of public health in England. The Lancet 2013;381(9873):1175. 
178. Middleton J, Williams G. England. In: Rechel B, Sagan AM, Hernández-Quevedo C, et al., eds. Organization and financing of public health services in Europe Country Reports Copenhagen: WHO Europe 2018:5-22.

179. Thomas C. Hitting the poorest worst? How public health cuts have been experienced in England's most deprived communities. London Institute for Public Policy Research (IPRR), 2019.

180. Health and local public health cuts. House of Commons Briefing 14.05.2019. London Local Government Association, 2019.

181. Marks L, Hunter DJ, Scalabrini S, et al. The return of public health to local government in England: changing the parameters of the public health prioritization debate? Public health 2015;129(9):1194-203.

182. CDC. Public Health's Infrastructure. Every health department fully prepared; every community better protected. A Status Report. Atlanta: CDC, 1999.

183. Khan AS, Levitt AM, Sage MJ. Biological and chemical terrorism; strategic plan for preparedness and response: recommendations of the CDC Strategic Planning Workgroup. 2000

184. Witt-Kushner J, Astles JR, Martin RA. Core functions and capabilities of state public health laboratories; a report of the Association of Public Health Laboratories. 2002

185. Davis RM. Healthy People 2010: objectives for the United States: Impressive, but unwieldy: British Medical Journal Publishing Group, 2000.

186. The Future of The Public's Health in the 21st Century. Washington DC: Institute of Medicine, 2003.

187. Rosner D, Markowitz G. Are we Ready? Public Health since 9/11 Berkeley et al. : University of California Press 2006.

188. Turnock BJ. Public Health Preparedness At A Price: Illinois. New York: Century Foundation, 2004.

189. Milne KC, Milne TL. Public health laboratory system improvement program: development and implementation. Public Health Reports 2010;125(2_suppl):31-39.

190. Gostin LO, Wiley LF. Public health law: power, duty, restraint: Univ of California Press 2016.

191. CDC. Public Health Preparedness: Mobilizing State by State. Atlanta: Centers for Disease Control and Prevention, 2008.

192. Boxrud D, Monson T, Stiles T, et al. The role, challenges, and support of pulsenet laboratories in detecting foodborne disease outbreaks. Public Health Reports 2010;125(2_suppl):57-62.

193. Inhorn SL, Astles JR, Gradus S, et al. The state public health laboratory system. Public Health Reports 2010;125(2_suppl):4-17.

194. Schrag SJ, Brooks JT, Van Beneden C, et al. SARS surveillance during emergency public health response, United States, March-July 2003. Emerging infectious diseases 2004;10(2):185.

195. Khan AS. Public health preparedness and response in the USA since 9/11: a national health security imperative. The Lancet 2011;378(9794):953-56.

196. Draper DA, Hurley RE, Lauer JR. Public health workforce shortages imperil nation's health: Center for Studying Health System Change 2008.

197. APHL. Lessons from a Virus. Public Health Laboratories Respond to the H1N1 Pandemic: Association of Public Health Laboratories, 2011.

198. Wilson ML, Gradus S, Zimmerman SJ. The role of local public health laboratories. Public Health Reports 2010;125(2_suppl):118-22. 
199. CDC. Improving the Nation's Ability to Detect and Respond to 21st Century Urgent Health Threats: Second Report of the National Biosurveillance Advisory Subcommittee. Atlanta: Centers for Disease Control and Prevention, 2011.

200. Tracking COVID-19 in the United States. From Information Catastrophe to Empowered Communities: Vital Strategies - Resolve to Save Lives, 2020.

201. Ridderhof JC, Wilcke Jr BW. Public health laboratory systems: at the crossroads: SAGE Publications Sage CA: Los Angeles, CA, 2013.

202. Loring C, Neil RB, Gillim-Ross L, et al. Using fee-for-service testing to generate revenue for the 21 st century public health laboratory. Public Health Reports 2013;128(2_suppl):97-104.

203. Malcarney M-B, Seiler N, Horton K. Public health laboratories and the Affordable Care Act: what the new health-care system means for public health preparedness. Public health reports 2015;130(5):543-46.

204. Himmelstein DU, Woolhandler S. Public health's falling share of US health spending. American journal of public health 2016;106(1):56-57.

205. Richards CL, Iademarco MF, Anderson TC. A new strategy for public health surveillance at CDC: improving national surveillance activities and outcomes. Public Health Reports 2014;129(6):472-76.

206. Maddox N. 100 Years of Influenza: Will Public Health Be Ready for the Next Pandemic. APHL Lab-Matters 2018(Winter)

207. Time to Welcome the Next Generation of PHL Scientists. Lab-Matters 2016(Fall)

208. Invisible No More: Sharing the Value of Health Laboratories. APHL Lab-Matters 2017(Summer)

209. Alesse L. Did Trump try to cut the CDC's budet as Semocrats claim? Analysis. $A B C$ News 2020 29.02.2020.

210. Gesetz zur Verhütung und Bekämpfung von Infektionskrankheiten beim Menschen (Infektionsschutzgesetz - IfSG). In: Bundesgesetzblatt I Bundesanzeiger Verlag, 2000:1045.

211. Wirtz A, Andres M, Gottschalk R, et al. Rolle der Gesundheitsbehörden der Länder bei der Verhütung und Bekämpfung von Infektionskrankheiten. BundesgesundheitsblattGesundheitsforschung-Gesundheitsschutz 2005;48(9):971-78.

212. Dreesman J, Benzler J. Surveillance übertragbarer Krankheiten auf der Grundlage des Infektionsschutzgesetzes in Deutschland durch den öffentlichen Gesundheitsdienst. Bundesgesundheitsblatt-Gesundheitsforschung-Gesundheitsschutz 2005;48(9):979-89.

213. Infektionsepidemiologisches Jahrbuch meldepflichtiger Krankheiten für 2001. Berlin: Robert Koch Institut, 2002.

214. Krause G, Altmann D, Faensen D, et al. SurvNet electronic surveillance system for infectious disease outbreaks, Germany. Emerging infectious diseases 2007;13(10):1548.

215. Smyth C. NHS fails to cope with bodies in flu pandemic test. The Times 2016 27.12.2016.

216. A World At Risk. Annual Report on Global Preparedness for Health Emergencies. Geneva: World Health Organisation, 2019.

217. Pandemic Preparedness Financing - Status Update. Washington DC: World Bank Group, 2019.

218. Report of the Review of NHS Pathology Services in England. Chaired by Lord Carter of Coles. London: Department of Health, 2006.

219. Health Protection Agency. Annual Report \& Accounts. London: Health Protection Agency, 2007.

220. Public Health England (PHE). Evaluation and Recommendations. IANPHI 2017. 
221. Summary of updated health protection legislation (England). London: Chartered Institute of Environmental Health, 2010. 


\section{Acknowledgements}

The author would like to thank Prof Gordon Dougan, Prof Christoph Gradmann, Dr Charlotte Kirchhelle, Prof Clare Chandler, Dr Ann Kelly, Dr Javier Lezaun, and Dr Christopher Sirrs for their valuable input on this paper. 